

\section{DISCLAIMER}

This report was prepared as an account of work sponsored by an agency of the United States Government. Neither the United States Government nor any agency Thereof, nor any of their employees, makes any warranty, express or implied, or assumes any legal liability or responsibility for the accuracy, completeness, or usefulness of any information, apparatus, product, or process disclosed, or represents that its use would not infringe privately owned rights. Reference herein to any specific commercial product, process, or service by trade name, trademark, manufacturer, or otherwise does not necessarily constitute or imply its endorsement, recommendation, or favoring by the United States Government or any agency thereof. The views and opinions of authors expressed herein do not necessarily state or reflect those of the United States Government or any agency thereof. 


\section{DISCLAIMER}

Portions of this document may be illegible in electronic image products. Images are produced from the best available original document. 


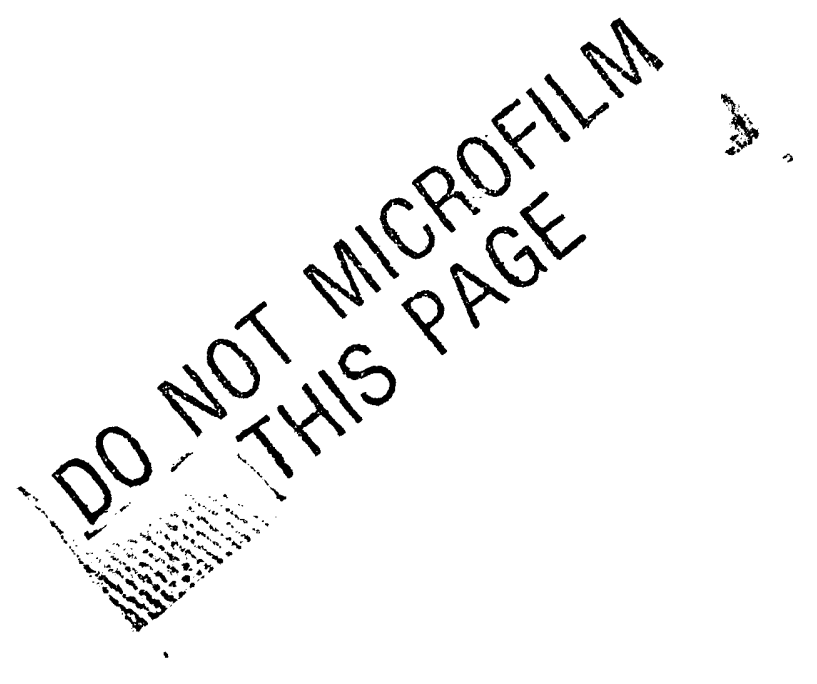

Printed in the United States of America. Available from
National Technical Information Service
U.S. Department of Commerce
5285 Port Royal Road, Springfield, Virginia 22161
NTIS price codes-Printed Copy: A05 Microfiche A01

This report was prepared as an account of work sponsored by an agency of the United States Government. Neither the United States Government nor any agency thereof, nor any of their employees, makes any warranty, express or implied, or assumes any legal liability or responsibility for the accuracy, completeness, or usefulness of any information, apparatus, product, or process disclosed, or represents that its use would not infringe privately owned rights. Reference herein to any specific commercial product, process, or service by trade name, trademark, manufacturer, or otherwise, does not necessarily constitute or imply its endorsement, recommendation, or favoring by the United States Government or any agency thereof. The views and opinions of authors expressed herein do not necessarily state or reflect those of the United States Government or any agency thereof. 
ORNL/TM- $-8347 / R 1$

DE8 3010978

Contract No. W-7405-eng-26

OPERATIONS DIVISION
ORNL/TM-8347/R1

Dist. Category UC-71

SAFETY-ANALYSIS REPORT FOR PACKAGING: THE ORNL DOT SPECIFICATION 20WC-5 - SPECIAL FORM PACKAGING

R. W. Schaich

Date Published - October 1982

Revised March 1983

NOTICE This document contains information of a preliminary nature. It is subject to revision or correction and therefore does not represent a final report.

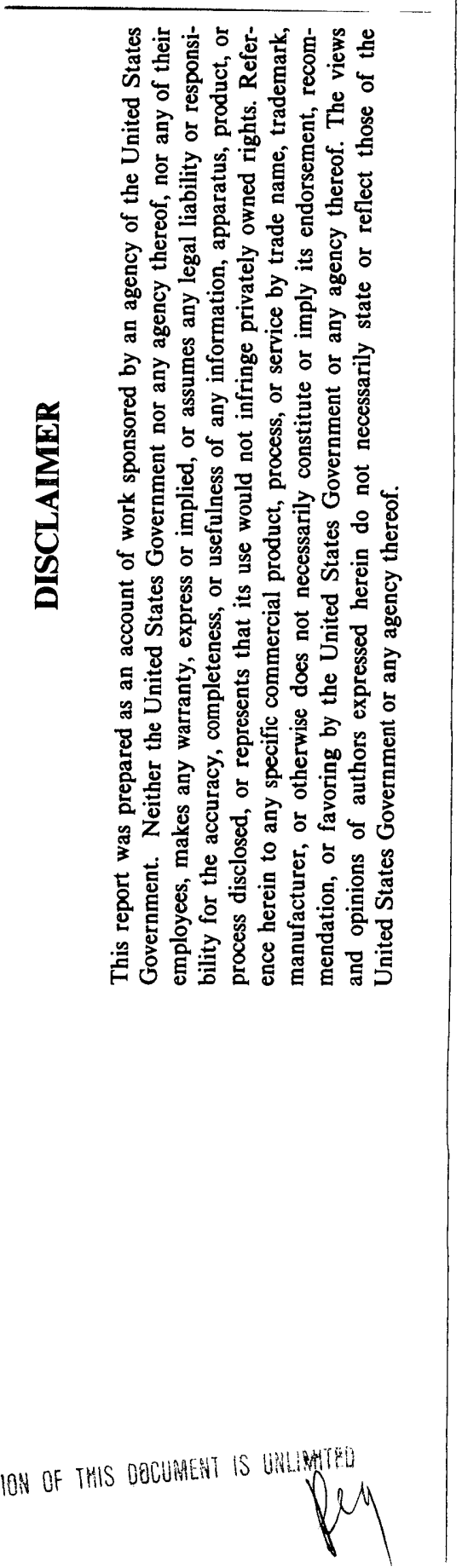

OAK RIDGE NATIONAL LABORATORY

Oak Ridge, Tennessee 37830

operated by

UNION CARBIDE CORPORATION

for the

U.S. DEPARTMENT OF ENERGY

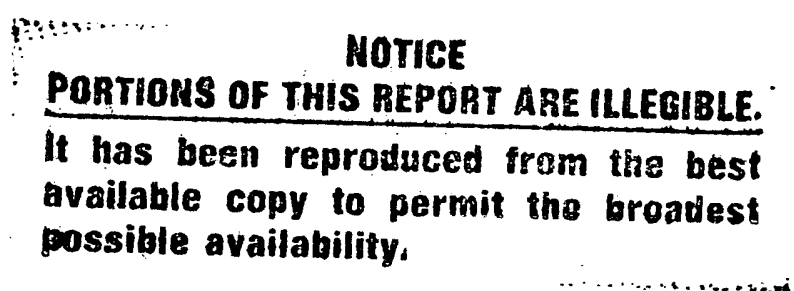




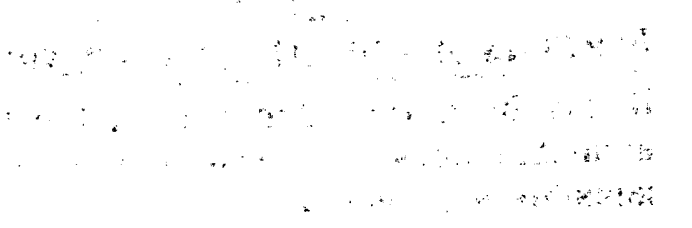


CONTENTS

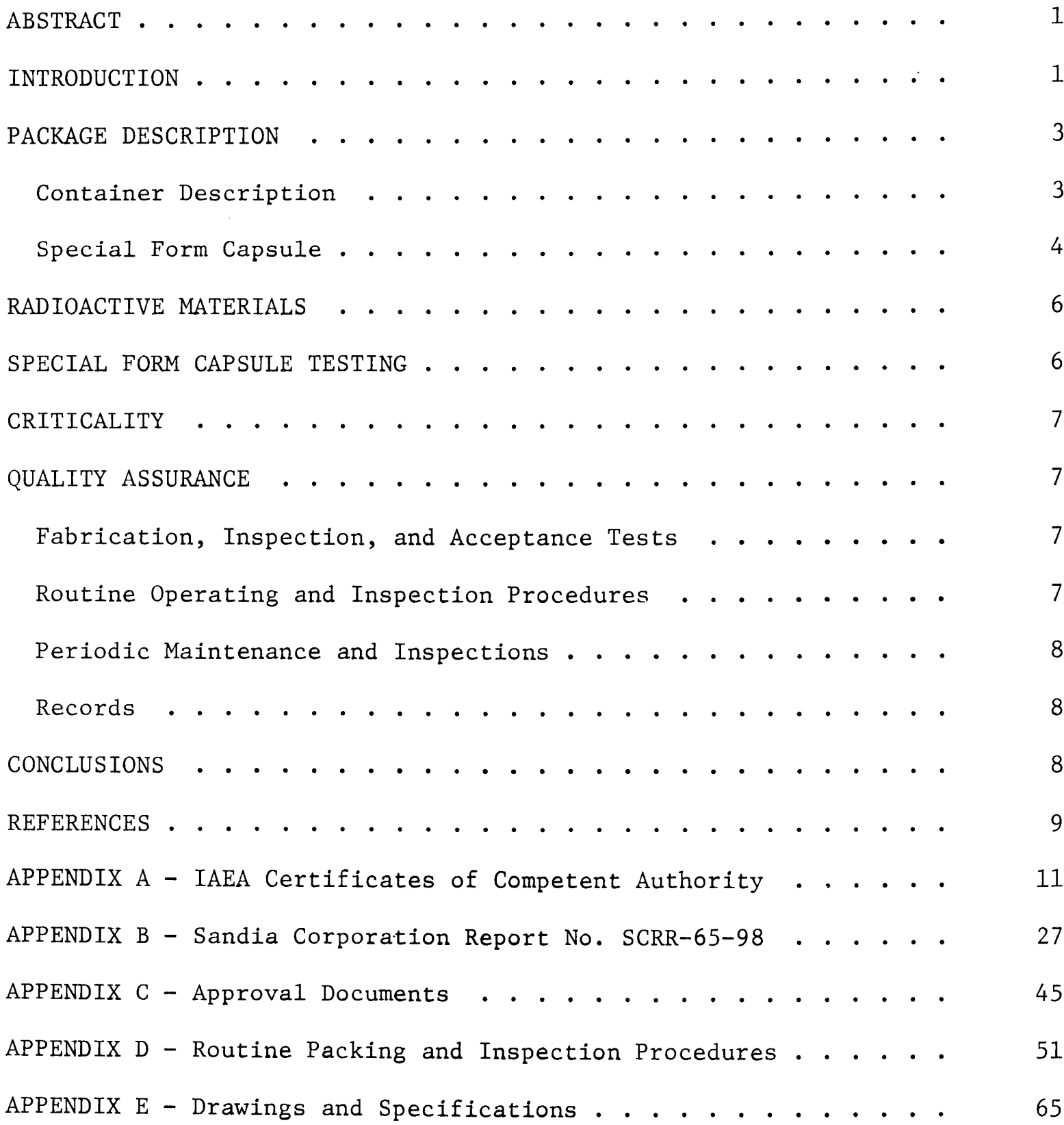




\section{LIST OF FIGURES}

FIGURE

1 ORNL DOT Specification 20WC-5 - Special Form Package . . . . 2

2 Typical ORNL Special Form Capsule - Type Am-1 . . . . . . 5

A1 Am-1 Powder Shipping Can, ORNL Dwg C-SK 1719 . . . . . . . 67

A2 Fire Shield-Sugarman Carrier USA/DOT 20WC-5, ORNL Dwg D-SK 1386 . . . . . . . . . . . . . . . . 68

A3 Fire Shield-Sugarman Carrier, USA/DOT 20WC-5, ORNL Dwg. D-SK 1387 ... . . . . . . . . . . . . . . . 69

A4 Fire Shield-Sugarman Carrier USA/DOT 20WC-5, ORNL Dwg D-SK 1389 . . . . . . . . . . . . . . . . . . . 70

A5 Radioisotope Shipping Container, ORNL Dwg X3D-10191-109 • • 71 


\section{SAFETY ANALYSIS REPORT FOR PACKAGING: THE ORNL DOT SPECIFICATION 2OWC-5 - SPECIAL FORM PACKAGING}

R. W. Schaich

Operations Division

Oak Ridge Nationa1 Laboratory

ABSTRACT

The ORNL DOT Specification 20WC-5 - Special Form Packaging was fabricated at the Oak Ridge National Laboratory (ORNL) for the transport of large quantities of solid non-fissile radioactive materials in special form. The package was evaluated on the basis of tests performed at Sandia National Laboratories, Albuquerque, New Mexico (formerly Sandia Corporation), on an identical fire and impact shield and special form tests performed on a variety of stainless steel capsules at ORNL by Operations Division personnel. The results of these evaluations demonstrate that the package is in compliance with the applicable regulations for the transport of large quantities of non-fissile radioactive materials in special form.

\section{INTRODUCTION}

The ORNL DOT Specification 20WC-5 - Special Form Packaging (Fig. 1) was fabricated at the Oak Ridge National Laboratory (ORNL) to meet the transport requirements of the Safety Series No. 6 "Regulations for Safe Transport of Radioactive Materials," 1973 Revised Edition, International Atomic Energy Agency (IAEA). The package is designed to ship large quantities of solid non-fissile radioactive materials in special form. The package was analyzed on the following basis: 1) Special Form tests performed by ORNL on a variety of stainless steel capsules which have been issued IAEA 


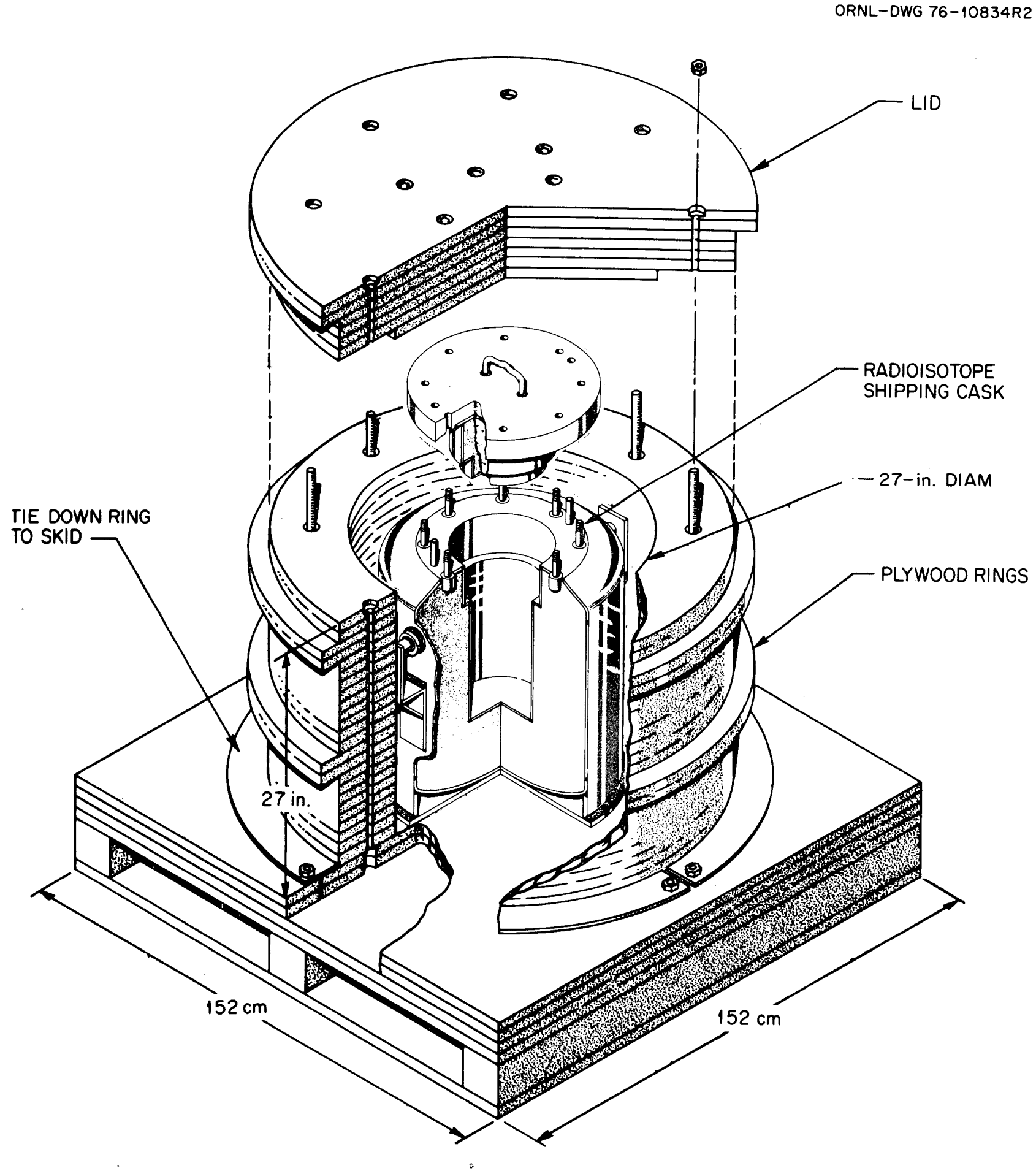

Figure 1. ORNL DOT-20WC-5 - Special Form Paekaging Weight $-40001 \mathrm{~b}(1815 \mathrm{Kg})$ 
Certificates of Competent Authority (Appendix A) and 2) Tests performed by the Sandia National Laboratories, Albuquerque, New Mexico (formerly Sandia Corporation), on identical fire and impact shields (Appendix B).

The primary use of the package is to provide shielding and impact and thermal resistance for its contents during transport for both normal and hypothetical accident conditions. The package can be used for the rail, highway, air, and water transport of large quantities of radioactive material in special form. It complies with the regulations contained in Title 10, Code of Federal Regulations, Part $71 ;^{1}$ DOE Manual Chapter $5480.1 ;^{2}$ and all Immediate Action Directives (IAD) in effect as of this report date. The package also complies with U.S. Department of Transportation (DOT) regulations published in Title 49, Code of Federal Regulations, Part 173; ${ }^{3}$ and the IAEA regulations found in Safety Series No. 6 "Regulations for the Safe Transport of Radioactive Materials,"1973 Revised Edition. 4

Calculations, engineering logic, and all related documents which demonstrate compliance with specifications are presented in Appendices A and $B$ of this report. Copies of the approval documents are reproduced in Appendix C.

\section{PACKAGE DESCRIPTION}

\section{Container Description}

The outer container consists of a U.S. Department of Transportation (DOT) Specification 20WC-5 wood overpack (49 CFR 178.194 and 173.394) which is approved by the DOT for the shipment of large quantities of radioactive material in Special Form. This packaging concept was tested by the Sandia National Laboratories in 1964 (Appendix B). The inner container 
consists of a stainless steel clad-lead shielded container which has been tested at ORNL to meet the Type A classification of the DOT and the IAEA (Appendix C). Special form capsules containing cobalt-60, iridium-192, cesium-137, strontium-90, and other beta/gamma emitters can be shipped in this package due to its shielding characteristics. Appendix D contains the ORNL procedures for the inspection and packaging of Type B packages prior to shipment.

\section{Special Form Capsule}

The encapsulation consists of two concentric cans, both constructed of stainless steel, which has a melting point of approximately $1375^{\circ} \mathrm{C}\left(2000^{\circ} \mathrm{F}\right)$ and meets all requirements listed in References 1-4. The IAEA Certificates of Competent Authority (USA/0156/S, USA/0198/S, USA/0202/S, USA/0203/S, USA/0204/S, USA/0205/S, and USA/0206/S) (Appendix A) give the detailed dimensions of the parts before assembly. Figure 2 shows a typical ORNL Special Form Capsule Am-1. For shipment of non-fissile radioactive materials, a weighed quantity of the dry radioactive material is introduced into the liner, then the interference-fit plug is pressed into the liner until the upper surface of the plug is flush with the lip of the liner. The plugged liner is then wiped to remove gross contamination. The liner is inserted into the containment capsule and the capsule plug is pressed in until the upper surface of the plug is flush with the lip of the capsule. The capsule is then seal-welded by a tungsten-inert gas method. The procedures used for welding the capsule were developed by welding and destructively examining units of identical design and material. The completed capsule is leak-tested by the ethylene glycol-vacuum technique (American National Standard N 542, A2.2.1) then cleaned to a contamination level of 
ORNL-DWG $80-14183$

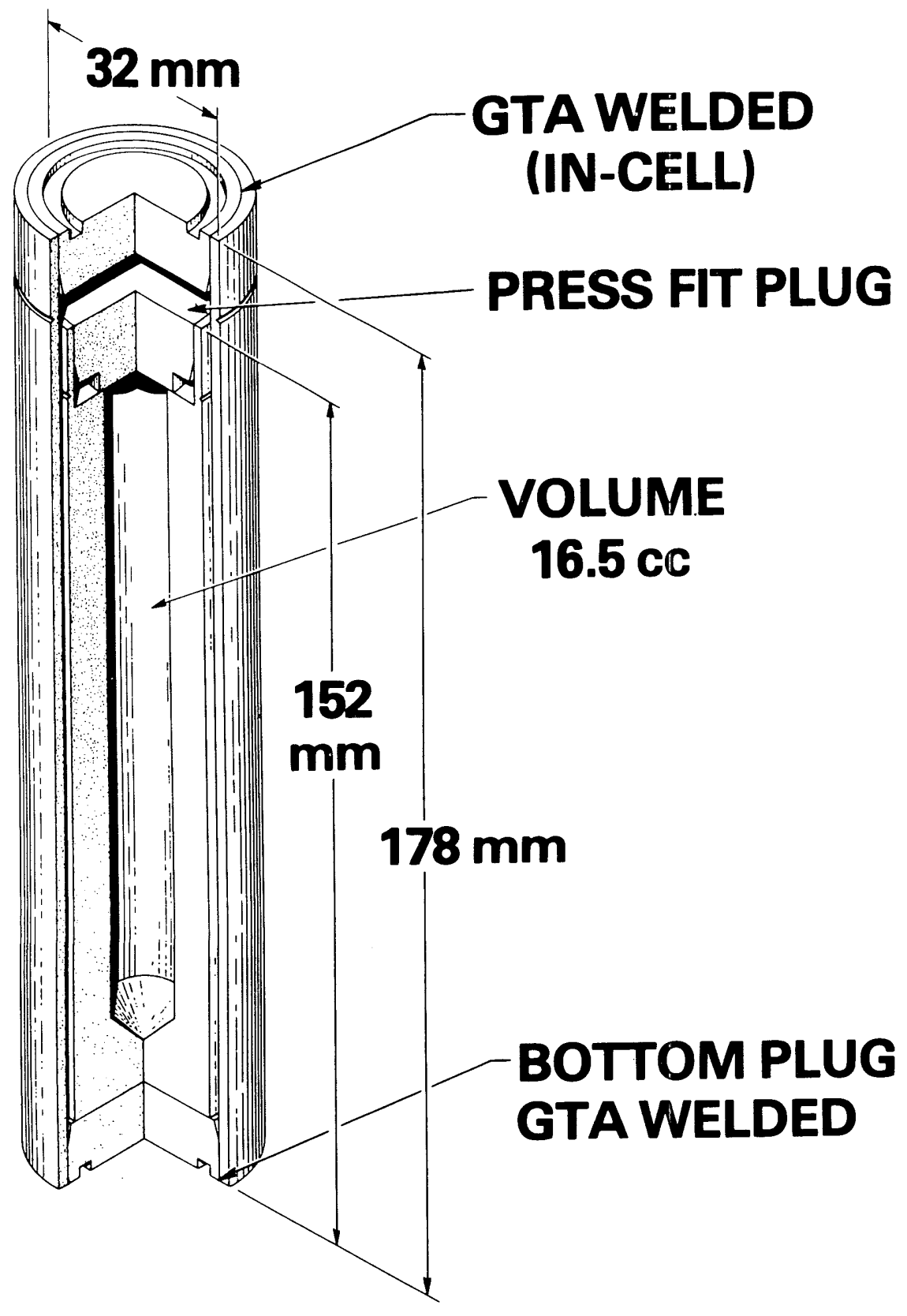

Figure 2. Typical ORNL Special Form Capsule - Type Am-1 
less than 0.005 microcuries per $100 \mathrm{~cm}^{2}$ before insertion into the DOT Specification 7A shielded container. Appendix D contains the ORNL procedures for leak testing special form capsules prior to shipment.

\section{RADIOACTIVE MATERIALS}

The maximum quantities of non-fissile radioactive materials to be shipped are limited to a radioactive thermal decay energy of 100 watts. Only one type of radioactive material will be shipped in a given capsule. In each case the radionuclide is in a relatively inert chemical form which will not melt, sublime, oxidize, or decompose at the temperatures and conditions normally encountered during shipment. The materials will be in either powder or pelletized form. The radiochemical purity of the radionuclides will be such that contributions from other radionuclides, except daughter products, will be insignificant.

\section{SPECIAL FORM CAPSULE TESTING}

Prototype capsules, except for the radioactive material content, were fabricated and subjected to the tests prescribed in References 1-4. The same capsule was used for each series of tests. Before and after each test the capsule was examined by microscope and leak-tested by both the ethylene glycol-vacuum and a helium leak test sensitive to leak rate $<1.0 \times 10^{-7} \mathrm{STD} \mathrm{cm} / \mathrm{sec}$. No leakage or other evidence of release of contents was detected after any of the tests. Test records are on file at Oak Ridge National Laboratory. 


\section{CRITICALITY}

Since no fissile materials are to be transported, a criticality evaluation is not necessary for this package.

QUALITY ASSURANCE

The regulations ${ }^{1-4}$ require packaging to be designed, fabricated, and operated in conformance with an established formal quality assurance program. Compliance with this requirement is discussed in the following subsections.

Fabrication, Inspection, and Acceptance Tests

The fabrication, inspection, and acceptance tests for typical special form capsules and containers are specified in Appendix E. The welds will be made and inspected according to the drawing. The ferrous materials to be used in the containers are specified on the data sheets to ASTM standards. Inspection of dimensions and finishes are performed to ensure that they are within the specified tolerances. Copies of the inspection reports are retained in an auditable file at ORNL.

\section{Routine Operating and Inspection Procedures}

The ORNL Operations Division has established routine operating and inspection procedures and standard checklists to ensure that all shipments are safe, comply with the regulations,,$^{-4}$ and comply with all ORNL procedures and regulations. Copies of the procedures and the checklists are presented in Appendix D. 


\section{Periodic Maintenance and Inspections}

Prior to each shipment, routine inspections are performed according to procedures and checklists. The ORNL procedures are presented in Appendix D as an example. Maintenance is required only when routine inspections indicate damage. There are no time-degradable materials used in the construction of the package except plywood used in the construction of the outside containers. Any damage or degradation to this material would be detected during routine inspection and replacement effected.

\section{$\underline{\text { Records }}$}

It is the responsibility of the ORNL Operations Division to assure that the containers are fabricated to the specifications on the drawings and specification sheets. In addition, the ORNL Operations Division shall maintain fabrication and inspection records in an auditable form for the life of the container.

\section{CONCLUSIONS}

Based on the Sandia National Laboratories (Appendix B) report on the testing of the identical overpacks and the IAEA Special Form Certificates of Competent Authority (Appendix A), it is concluded that the ORNL DOT Specification 20WC-5 - Special Form Packaging meets all pertinent regulations concerning the shipment of large quantities of solid non-fissile radioactive material in special form. 


\section{REFERENCES}

1. Title 10, Code of Federal Regulations, Part 71, "Packaging of Radioactive Material for Transport and Transportation of Radioactive Materials Under Certain Conditions."

2. U.S. Department of Energy, Environmental Protection Agency, Safety and Health Protection Program for DOE Operations, DOE 5480.1.

3. Title 49, Code of Federal Regulations, Part 173, "Transportation."

4. International Atomic Energy Agency, Safety Series No. 6 "Regulations for the Safe Transport of Radioactive Materials," 1973 Revised Edition. 

APPENDIX A

IAEA CERTIFICATES OF COMPETENT AUTHORITY 



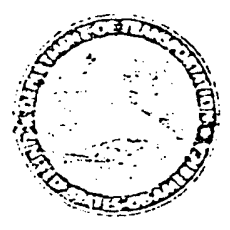

\author{
DEPARTMENT OF TRANSPORTATION \\ RESEAFCH AND SPECIAL PROGRAMS ADMINISTPATION \\ WASHINGTON. D.C. 20590 \\ IAEA CEIEIFICATE OF OCMPETENT ALTHORTTY \\ Special Form Padioactive Meterial Encapsulaiion \\ REFER TO:
}

Cerrificate Number USA/0156/S

Inis certifies that the ercapsulated source, as described, winen loaded with the authorized radicactive contents, has been demonstrated to meet the regulatory requirements for special form radioactive material as prescribed in IAEA 1 and USA 2 regulations for the transport of radioactive materials.

I. Source Description - The source described by this certificate is icientiried as the Type I Powder Shipping Can which is a 304-I stainless steel welced encapsulation reasuring 0.75 incies in diareter by 3.0 inches in length constructed as described in Union Carbide Nuclear Division drawing B-RD 3092.

II. Radioactive contents - The authorized radioactive contents of this sourro consist of not more than:

\begin{tabular}{|c|c|c|}
\hline Radionuclide & Form & $\begin{array}{l}\text { Maximum Content, } \\
\text { Curies per Capsule }\end{array}$ \\
\hline Americium-241 & Oxide, $\mathrm{AmO}_{2}$ & 50 \\
\hline Americium-243 & Oxide, $\mathrm{AnnO}_{2}$ & 3 \\
\hline Cesium-137 & Chloride, CsCl & 375 \\
\hline Cobalt-60 & Metal & 5,000 \\
\hline Curium-244 & Oxide, $\mathrm{CmO}_{2}$ & 1,000 \\
\hline Iridium-192 & Metal & 5,000 \\
\hline Neptunium-237 & Oxide, $\mathrm{NpO}_{2}$ & 0.01 \\
\hline Plutonium-238 & Oxide, $\mathrm{PuO}_{2}$ & 250 \\
\hline Plutonium-239 & Oxide, $\mathrm{PuO}_{2}$ & 0.90 \\
\hline Plutonium-240 & Oxide, $\mathrm{PuO}_{2}$ & 3.40 \\
\hline Plutonium-241 & Oxide, $\mathrm{PuO}_{2}$ & 1,500 \\
\hline Plutonium-242 & Oxide, $\mathrm{PuO}_{2}$ & 0.06 \\
\hline Promethium-147 & Oxide, $\mathrm{Pm}_{2} \mathrm{O}_{3}$ & 5,000 \\
\hline Strontium-90 & Fluoride, $\mathrm{SrF}_{2}$ & 450 \\
\hline Strontium-90 & Oxide, Sro & 450 \\
\hline Strontium-90 & $\begin{array}{l}\text { Titanate, } \mathrm{SrO} \cdot\left(\mathrm{TiO}_{2}\right) \\
\text { where } x \geq 0.5\end{array}$ & 450 \\
\hline Thorium-230 & Oxide, $\mathrm{ThO}_{2}$ & 0.30 \\
\hline Uraniun-233 & Oxide, $\mathrm{v}_{3} \mathrm{O}_{8}$ & 0.14 \\
\hline Uranium-233 & Metal & 0.14 \\
\hline Uranium-234 & Oxide, $\mathrm{U}_{3} \mathrm{O}_{3}$ & 0.09 \\
\hline
\end{tabular}


Certificate Number USA/0156/S Revision 1

III. This certificate, unless renewed, expires February 28, 1983.

This certificate is issued in accoralance with parauraph 803 of the IAEA Pscqulations 1, and in response to the Cctober 24, 1980, petition by the Dek Pidge National Iaboratory, and in consiajeration of the associated information therein.

Certified by:

R. R. Rawl,

Crie?, Radioactive Materials Brancin

Office of Hazandous Materials Regulations

Materials Transportation Bureau

I "Safety Series No. 6, Regulations for the Safe Iransport of Radicactive Materials, 1967 Edition", published by the International Atcmic Energy Agency (IAEA), Vienna, Austria.

2 Title 49, Code of Federal pgulations, Part 170-178, USA.

Revision 1 issued to amend contents, reflect conformance with 1973 IAEA regulations and extend expiration date. 


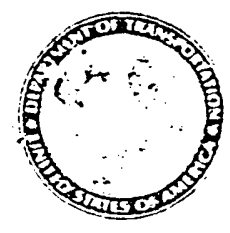

\author{
DEPARTMENT OF TRANSPORTATION \\ RESEARCH AND SPECIAL PROGRAMS ADMINISTRATION \\ WASHINGTON, D.C. 20590 \\ IAEA CERTIFICATE OF COMPETENT AUTHORITY
}

Special Form Radiozctive Material Encapsulation

Certificate Number USA/0198/S

This certifies that the encapsulated source, as described, when loaded with the authorized radioactive contents, has been demonstrated to meet the regulatory requirerents for special form radicactive materials as prescribed in IAEA I/ and USA 2/ regulations for the transport of radioactive materials.

I. Source Description - The source described by this certificate is identified as cak Riage National Laboratory Capsule An-l which is a double cylindical encapsulation constructed of 304L stainless steel with the outer capsule closed and sealed by welding. The outer capsule measures $1.25^{\circ}$ in outside dianeter by 7.0" in length.

II. Radioactive Contents - The authorized raaioactive contents of this source consist of:

\begin{tabular}{llr} 
Radionuclide & \multicolumn{1}{c}{ Form } & $\begin{array}{r}\text { Maximum Con } \\
\text { Curies per C }\end{array}$ \\
\cline { 3 - 3 } Americium-241 & Oxide, $\mathrm{AmO}_{2}$ & 130 \\
Americium-243 & Oxide, $\mathrm{AmO}_{2}$ & 8 \\
Curium-244 & Oxide, $\mathrm{CmO}_{2}$ & 3,000 \\
Neptunium-237 & Oxide, $\mathrm{NpO}_{2}$ & 0.03 \\
Plutonium-238 & Oxide, $\mathrm{PuO}_{2}$ & 680 \\
Plutonium-239 & Oxide, $\mathrm{PuO}_{2}$ & 2.50 \\
Plutonium-240 & Oxide, $\mathrm{PuO}_{2}$ & 10.0 \\
Plutonium-241 & Oxide, $\mathrm{PuO}_{2}$ & 4,000 \\
Plutonium-242 & Oxide, $\mathrm{PuO}_{2}$ & 0.15 \\
Promethium-147 & Oxide, $\mathrm{Pm}_{2} \mathrm{O}_{3}$ & 5,000 \\
Strontium-90 & Fluoride, SrF & 1,200 \\
Strontium-90 & Oxide, $\mathrm{SrO}_{2}$ & 1,200 \\
Strontium-90 & Titanate, SrO. $\left(\mathrm{TiO}_{2}\right)$ & 1,200 \\
where $x \geq 0.5$ & \\
Thorium-230 & Oxide, $\mathrm{ThO}_{2}$ & 0.80 \\
Uranium-233 & Oxide, $\mathrm{U}_{3} \mathrm{O}_{8}$ & 0.40 \\
Uranium-233 & Metal & 0.40 \\
Uranium-234 & Oxide, $\mathrm{U}_{3} \mathrm{O}_{8}$ & 0.25
\end{tabular}


Certificate Nunber USA/0198/S

Page 2

III. This certificate, unless renewed, expires Janaury 31, 1983.

This certificate is issued in accordance with paragraph 803 of the IAEA Regulations 1/, and in response to the October 24, 1980 petition by Oak Ridge National Iaboratory and in consideration of the associated infomation therein.

Certified by:

R. R. Rawl

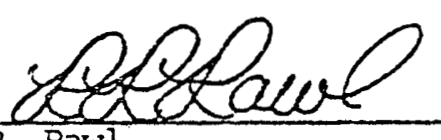

Chief, Radioactive Materials Branch

Office of Hazardous Materials Regulation

Materials Transportation Bureau

1/ "Safety Series No. 6, Regulations for the Safe Transport of Radicactive Materials, 1973 Revised Edition", published by the International Atomic Energy Agency (IAEA), Vienna, Austria.

2) Title 49, Code of Federal Regulations, Part 170-178, USA. 


\author{
DEPARTMENT OF TRAMSPORTATION \\ RESEARCH AND ISPEIAL PROGRAMS ADMINISTRATION \\ WASHINGTON. D.C. 20530 \\ IAEA CEPIIRICATE CF COMPETEAT AUTHCONTY
}

Spxial Fonn Radioactive Materials Encapsulation

Certificate Muber USA/0202/S

This certifies that the encausulated source, as described, when loaded with the authorlzed Iadioactive contents, has been demconstrated to meet the regulatory reguirements for special fom radioactive material as prescribed in IAFAI/ and USA2/ regulations for the transport of radicactive materials.

I. Source Description - The source described by this certificate is Identified as Cak pidre National Laboratory (OFan) ponder Shipping can Type 2 which is a turysten-ivert gas welded double encapsulation constructed of stainless steal. The capule is cylindrical with extecnal dimensions of $5^{\prime \prime}$ in length by $1.25^{\prime \prime}$ in diameter.

II. Radloactlve Dontents - The authaized radioactive contents of this source consist of not more than the following:

Radionuclide

Americiun-241

Americiun-243

Cesium -137

Cobalt -60

Curium-244

Iridium-192

Neptim. : $1 \mathrm{~m}-237$

Piutonium-238

Plutonium-239

Plutonium-240

Plutoniun-241

Plutonium-242

Promethium-147

Strontium-90

Strontium-90

Strontium-90

Thorium-230

Uranium-233

Uranium-233

Uraniun-234

\section{Form}

Oxide $\mathrm{AmO}_{2}$

Oxide, $\mathrm{AnO}_{2}$

Chloride, $\mathrm{CsCl}$

Metal

Oxide, $\mathrm{CnO} \mathrm{O}_{2}$

Hetal

Oxide, $\mathrm{NFO}_{2}$

Oxide, $\mathrm{PuO}_{2}$

Oxide, $\mathrm{PuO}_{2}$

Oxide, $\mathrm{PuO}_{2}$

Oxide, $\mathrm{PuO}_{2}$

Oxide, $\mathrm{PrO}_{2}$

Oxide, $\mathrm{Pni}_{2} \mathrm{O}_{3}$

Fluoride, $\mathrm{SrF}_{2}$

Oxide, Sro

Titanate, $\mathrm{SrO} \cdot\left(\mathrm{TiO}_{2}\right)_{x}$ where $x \geq 0.5$

Oxide, $\mathrm{ThO}_{2}$

oxide, $\mathrm{U}_{3} \mathrm{O}_{\mathrm{B}}$

Metal

Oxide, $U_{F} \mathrm{O}_{R}$
Maximum Content, Curies per Capsule 200

1,500

5.000

4,000

5,000

0.04

1,000

3.6

14.0

5,000

0.25

5,000

2,000

2,000

2,000

1.2

0.6

0.6

0.4 
III. This certificate, unless renewed, expires an February 1, 2984.

This certificate is 1ssy: in accordance with paragraph 803 of the IAEA pagulationsl/, ....i in response to the Cotober 24, 1980 petition by cak Ridge lational Laboratory and in consideration of the associated information therein.

Certified by:

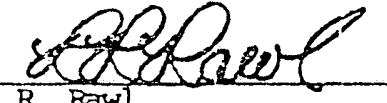

R. R. Rawl

Cilef, Radioactive Materlals Rranch Oifloe of Hazardous Materials pogulation

Materials Transportation Bureau

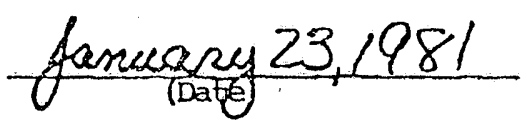

$1 /$ "Safety Series No. 6 pegulations for the Safe Transport of Padioactive Materials 1973 Fevised Edition", published by the International Atanic Energy Agency (IAEA), Vienna, Austria.

2f Title 49, Code of Federal Pegulations, Part 170-178, USA. 
8

US. Department of Transportation

400 Se ventn Street, S.W

Research and

Special Programs

Administration

IFEA CERTIFICATE OF COMPETENT AUTHORTTY

Special Form Radioactive Material Encapsulation

Certificate Number USA/0203/S

This certifies that the encapsulated source, as described, when loaded with the authorized radioactive contents, has been demonstrated to meet the regulatory requirements for special form radioactive material as prescribed in IAEA I/ and USA I/ regulations for the transport of radioactive materials.

I. Source Description - The source described by this certificate is identified as Oak Ridge National Iaboratory (ORNL) Powder Shipping Can Type 3 which is a tungsten-inert gas welded double encapsulation constructed of stainless steel. The capsule is cylindrical with external dimensions of $8 "$ in length by $1.25^{\prime \prime}$ in diameter.

II. Radioactive Contents - The authorized radioactive contents of this source consist of not more than:

\begin{tabular}{lll} 
Radionuclide & Form & $\begin{array}{c}\text { Maximm content, } \\
\text { Curies per Capsule }\end{array}$ \\
\cline { 2 - 3 } Cesium-137 & Chloride, CsCl & 4,000 \\
Cobalt-60 & Metal & 5,000 \\
Iridium-192 & Metal & 5,000 \\
Strontium-90 & Oxide, Sr0 & 5,000 \\
Strontium-90 & Fluoride, SrF2 & 5,000 \\
Strontium-90 & Titanate, Sr0. (Ti02)x & 5,000
\end{tabular}

III. This certificate, unless renewed, expires on February 1, 1984.

This certificate is issued in acoordance with paragraph 803 of the IAEA Regulations 1/, and in response to the October 24, 1980 petition by Oak Ridge National Laboratory and in consideration of the associated information therein. 
Certified by:

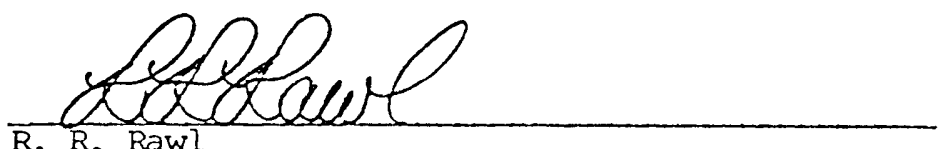

R. R. Rawl

Chief, Radioactive Materials Branch

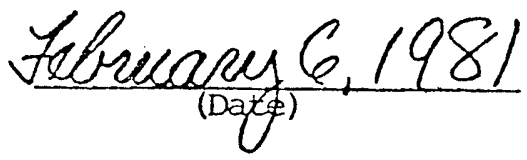

Office of Hazardous Materials Regulation

Materials Transportation Bureau

1/ "Safety Series No. 6, Regulations for the Safe Transport of Radioactive Materials, 1973 Revised Eäition", published by the International Atomic Energy Agency (IAEA), Vienna, Austria.

2/ Title 49, Code of Federal Regulations, Part 170-178, USA. 
8

US Deparimiont o! Tronsporticion

400 jerenth Swez: S $W$

Research and Speciol Program:

Administration

IAES CEETIFICATE OE COPETTER ALTHORITY

Special Form Radioactive Natorial Encapsulation

Certificate inmber USA/0204/S

This certifies that the encapsulated source, as described, when loaded with the autiorized radiaactive contents, has been demonstrated to meet the regulatory requirements for special form radiactive material as prescribed in IAEA 1/ and USA 2/ regulations for the transport of radioactive materials.

I. Source Description - The source described by this certificate is identifier as Cak Fidge National Laboratory (OFNL) ponder Shipping Can Type IV which is a tungsten-inert gas welded double encapsulation constructed of stainless steel. Tre capsule is cylindrical with extemal dimensions of $9^{\prime \prime}$ in length by $2.5^{\prime \prime}$ in diameter.

II. Radioactive contents - The authorized radioactive contents of this source consist of not more than:

Radionuclide

Cesilim- 137

Cobalt -60

Iridilitr-192

Strontium-90

Strantium-90

Strontium 90
Form

Chloride, $\mathrm{CsCl}$

Metal

Natal

oxide, sro

Fluoride, $\mathrm{SrF}_{2}$

Titinate, Sro. $\left(\mathrm{TiO}_{2}\right)$ uhiare $x$ is more thian 0.05
Naximum Content, Curies per Capsule

5,000

5,000

5,000

5,000

5,000

5,000

III. This certificate, unless renered, expires on Febuary 1, 1984.

This certificate is issued in accordance with paragraph 803 of the IAEA Regrulations 1/, and in response to the october 24, 1980 petition by Cak Ridge National Iabolatory and in consideration of the associated information therein. 
Certified bis:

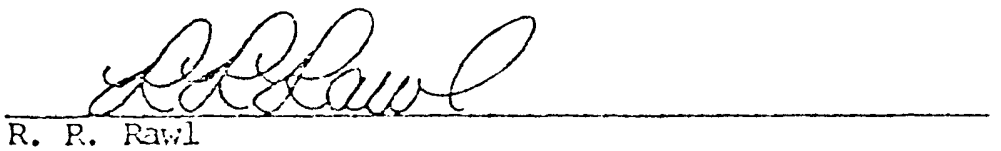

R. P. Raril

Chisf, Radicactive Raterials Branch Office of Hazardous itaterials Regulation

Materials Transportation Bureau

\section{$\frac{\text { tefereapy27,1981 }}{(\text { Date) }}$}

1/ "Safety Series No. 6, Regulations for the Safe Transport of Radioactive Taterials, 1973 Revised Edition", published by the Intemational Atomic Energy Agency (IAEA), Vienna, Austria.

2) Title 49, Code of Federal Regulations, Part 170-178, USA. 


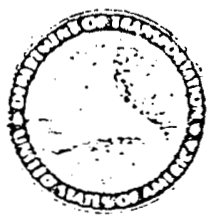

\author{
DE:PARTMENT OF TRANSPORTATION \\ RESEARCH ANO SPECIAL PROGRAMS ADMINISTRATION \\ WASMINGTON. D.C. 20590 \\ IAEA CERTIFICATE CE OCAPETENT AUTHORTTY
}

Special Fonn Radioactive Material Encapsulation

\title{
FEB 21981
}

Gertificate Number USA/0205/S

This certifies tho" the ers psulated source, as described, when loaded with the authorized rimlioactive contents, has been demonstrated to meet the regulatory requirements for special form radioactive material as prescribed in IAEA 1/ and USA 2/ regulations for the transport of radioactive materials.

I. Source Descrlption - The source described by this certificate is identified as Oak Ridge National Laboratory (CRNL) Capsule Ir-192 which is a tungsteninert gas welded stainless steel encapsulation. The source is cylindrical and has extermai dimensions of $2^{\prime \prime}$ in length by $0.5^{\prime \prime}$ in diameter.

II. Radioactive Contents - The authorized radioactive contents of this source cansist of not more than 5,000 curies of cobalt-60 or iridium - 192 as metal wafers or pellets.

III. This certificate, unless renewed, expires on Febnuary 1, 1984.

This certificate is iss'ed in accordance with paragraph 803 of the IAEA Regulations 1/, and in response to the October 24, 1930 perition by cak Ridge National Laboratory and in comsideration of the associated information therein. therein.

Certified by:

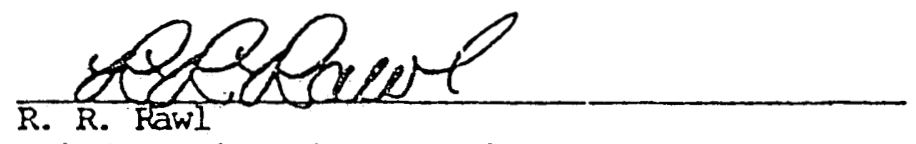

Crief, Radioactive Materials Pranch

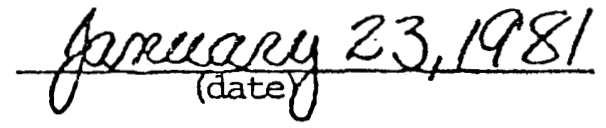

Office of Hazardous Materlals Pegulation

Materials Transportation Bureau

If "Safety Series No. E, Regulations for the Safe Transport of Radioactive Materials, 1973 Revisec! Edition", published by the International Atomic Energy (IAEA), Vienna, Austria.

2f Title 49, Code of FEderal Regulations, Part 170-178, USA. 


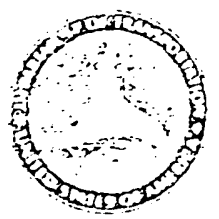

\author{
DE.PARTMENT OF TRANSPORTATION \\ RESEARCH AND SPECIAL PROGRAMS ADMINISTRATION \\ WASHINGTON. D.C. 20590 \\ IAEA CERTIFICAIE GF CORPETENT AUTHORTIY
}

Spocial Form. Fadicactive Materials Encapsulation

Certificate Mmber USA/0205/S

Tinis certifies that the encspsulated source, as described, when loaded with the authorized radioactive contents, has been demonstrated to meet the regulatcry requirements for special form radioactive material as prescribed in IAEAl/and USA2/ regulations for the transport of radioactive materials.

I. Source Description - The source described by this certificate is identified as Oak Ridge National Laboratory (ORNL) Capsule Pm-l which is a tungsten-inert gas welded double encapsulation constructed of stainiless steel. The source is cylindrical with extemal dimensions of 3 " in length by $125 "$ in diameter.

II. Radioactive Contents - The authorized radioactive contents of this source consist of not. more than:

\begin{tabular}{|c|c|c|}
\hline Radionuclide & Form & $\begin{array}{l}\text { Maximum Con } \\
\text { Curies per } \\
\end{array}$ \\
\hline Americium-241 & Oxide, $\mathrm{AmO}_{2}$ & 30 \\
\hline Americium-243 & Oxide, $\mathrm{AmO}_{2}$ & 2 \\
\hline Curium-244 & Oxide, $\mathrm{CmO}_{2}$ & 700 \\
\hline Neptunium-237 & Oxide, $\mathrm{NpO}_{2}$ & 0.01 \\
\hline Plutonium-238 & Oxide, $\mathrm{PuO}_{2}$ & 155 \\
\hline Plutonium-239 & Oxide, $\mathrm{PuO}_{2}$ & 0.60 \\
\hline Plutonium-240 & Oxide, $\mathrm{PuO}_{2}$ & 2.20 \\
\hline Plutonium-241 & Oxide, $\mathrm{PuO}_{2}$ & 1,000 \\
\hline Plutonium-242 & Oxide, $\mathrm{PuO}_{2}$ & 0.04 \\
\hline Promethium- 147 & oxide, $\mathrm{Pm}_{2} \mathrm{O}_{3}$ & 5,000 \\
\hline Strontium-90 & Fluoride, $\mathrm{SrF}_{2}$ & 300 \\
\hline Strontium-90 & Oxide, Sro & 300 \\
\hline Strontium-90 & $\begin{array}{l}\text { Titanate, } \mathrm{SrO} \cdot\left(\mathrm{TiO}_{2}\right)_{x} \\
\text { where } \mathrm{x} \geq 0.5\end{array}$ & 300 \\
\hline Thorium- 230 & Oxide, $\mathrm{ThO}_{2}$ & 0.20 \\
\hline Uranium-233 & oxide:,$U_{3} O_{8}$ & 0.10 \\
\hline Uranium-233 & Metal & 0.10 \\
\hline Uranium-234 & Oxide, $\mathrm{U}_{3} \mathrm{O}_{8}$ & 0.06 \\
\hline
\end{tabular}


III. This certificate, unless renexed, expires on February 1, 1984,

Inis certlficate is issued in ascordance with paragraph 803 of the IAEA. Fegulationsl/, and in respance to the Octaber 24, 1980 petitica by cak Ridge vational Laboratory and in cansideration of the associated information therein.

Certified $b_{x}^{\prime}$ :

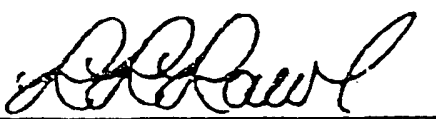

R. R. Raw1

U. S. Department of Transportation Office of Hazardous Materials Regulation Washington, D.C. 20590

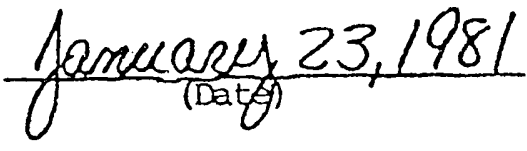

1/ "Safety Series No. 6, Regulations for the Safe Transport of Radioactive Materials, 1973 Revised Edition", published by the International Atanic Energy' Agency (IAEA), Vienna, Austria.

2) Title 49, Code of Federal Regulations, Part 170-178, USA. 
APPENDIX B

SANDIA CORPORATION REPORT NO. SCRR-65-98 

TID-4500 (41st Ed.)

WASTE DISPOSAL AND PROCESSING

SC-RR-65-98

PROCEEDINGS OF THE INTERNATIONAL

SYMPOSIUM FOR PACKAGING AND

TRANSPORTATION OF RADIOACTIVE MATERIALS

\author{
Sponsored by \\ Sandia Corporation \\ U. S. Atomic Energy Commission
}

Held at

Albuquerque, New Mexico

January 12-15, 1965

June 1965 


\title{
NEW DEVELOPMENTS IN ACCIDENT RESISTANT SHIPPING CONTAINERS FOR RADIOACTIVE MATERIALS
}

\author{
J. A. Sisler
}

\section{Introduction}

The production of radioactive isotopes has greatly increased since scientists have learned how to control the reaction of fissionable materials in numerous types of reactors. With the production of the various isotopes came their commercial utilization. When any product has a commercial application, it is introduced into interstate and international commerce and involves one or more modes of transportation. Because radioactive materials are hazardous in varying degrees, their shipment falls within the purview of certain agencies established by law to regulate shipment in interstate or international traffic.

Both the severe consequences that could result from an accidental release of the more dangerous radioactive materials and the public's fear of this silent, unseen hazard prompted regulatory agencies such as the Interstate Commerce Commission (ICC), the Air Transport Association (ATA), and the Bureau of Explosives (B of E) to meet with their counterparts in other nations to consider proposed regulations to control the shipment of radioactive materials. These proposed regulations impose more severe container requirements upon the user and shipper of radioactive materials. These proposals, establishing criteria for radioactive-material containers for national and international traffic, require that a container survive a series of conditions which might occur during an accident. The conditions for containers of certain classes of radioactive materials are simulated in the following sequence:

1. A 30-foot free fall to an unyielding surface.

2. A 40-inch drop onto a 6-inch-diameter by 8-inch-long carbon-steel spike. The container shall be positioned to cause the maximum damage in both drops.

3. An ASTM standard 1-hour fire.

4. A 24-hour submersion of the container in water to a depth of 3 feet over the uppermost portion of the container without leakage of the contents or loss of any shielding.

Since the 1-hour fire is considered the most severe obstacle to overcome in the above test sequence, the Atomic Energy Conmission (AEC) requested Sandia Corporation, with their extensive environmental testing facilities and the knowledge gained in performing numerous 
open-pit fire tests and radiant heat tests, help in developing containers for shipping radioactive materials that would withstand the above test sequence and to assist in the subsequent formulation of appropriate regulations.

\section{Program Feasibility}

At the outset of the container development work, it was decided that existing containers must be retained because the national inventory of radioactive-material shipping containers is so great that it would be wasteful to dispose of this inventory. Consequently, it was decided to develop an outer shell which would enable existing containers to meet the test criteria and, simultaneously, to establish a concept which would permit simpler future container designs.

Since preliminary evaluation of the test parameters indicated that the fire environment presented the greatest design difficulties, maximum effort was concentrated upon controlling the fire environment by means of insulating and ablative materials, or a combination of the two. However, insulating materials were discarded early in the program because of either the difficulties of container fabrication or failure to meet the drop-rest criteria. It should be noted, however, that a steel encased, gypsum-cement insulated container successfully passed the fire test.

In considering the use of ablative materials, several factors had to be evaluated: material cost, availability, structural integrity, and ease of fabrication. These factors unerringly pointed to wood as the most suitable material. The mechanics of wood combustion through destructive distillation, the formation of a low-density char with good insulation properties, and the reasonably good insulation characteristics of the wood itself indicated that a full-scale test and development program should be initiated using this material.

\section{Test Program}

\section{Drop Tests}

To meet the drop-test criterion of a 30-foot free fall to an unyielding surface, Sandia's 185-foot drop-tower complex, capable of handling containers up to 16,000 pounds, was utilized. The containers were dropped from 30 feet onto a reinforced concrete pad with the drop angle controlled. Although only one 30-foot drop is required, the small to medium-size containers usually were dropped three times, once each on an edge, a side, and the bottom. The smaller containers were so slightly damaged by only one drop that the data obtained might have resulted from minor variations in construction rather than from damage. This drop resistance results from the thick wall required for fire resistance. Large containers were generally dropped only once in the most damaging position. However, as a proof test, one 4000-pound container was dropped three times--once at 45 degrees, once on a side, and once on an end. 
Because the drop-test criterion of a 40-inch fall onto a 6-inchdiameter spike is a recent addition to the regulation, tests against this requirement have not been performed to date. However, meeting this requirement is not considered to be a problem.

\section{Fire Tests}

To meet the test requirement of an ASTM standard 1-hour fire, an open-pit petroleum fire with JP-4 jet fuel (Figure 1) was used, although it mist be recognized that this is a more extreme test than required by the ASTM standard curve. It has been found that a minimum fuel area of 400 square feet and a maximum of 2000 square feet ${ }^{2}$ was optimum for maximum heat input to the container. The container array was adjusted so that a minimum of 2 to 3 feet of flame would completely surround each container. This is equivalent to an infinite wall of flame and maximizes heat input to the object under test. We have found that in a fire of this size, radiation is the dominant heattransfer mode, Thus, for computer studies, an $1850^{\circ} \mathrm{F}$ black-body temperature can be used as the input figure and will give close correlation for a modeling study. ${ }^{2}$

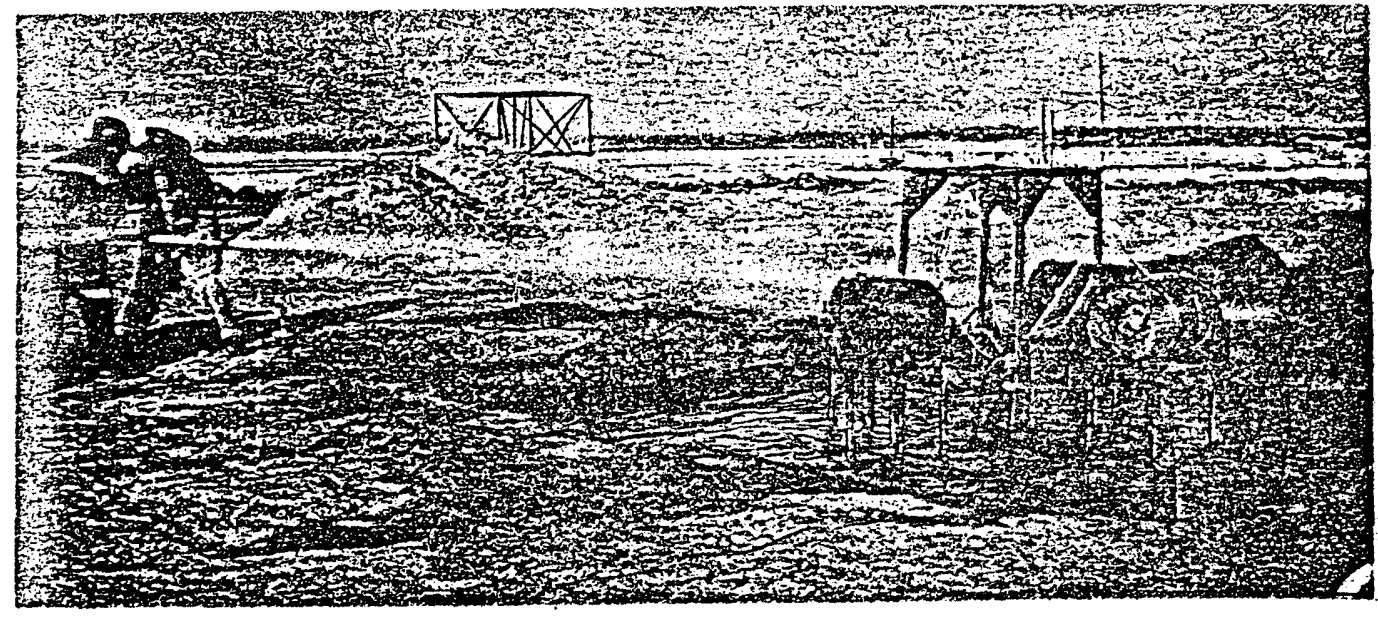

Figure 1. $20 \times 20$-foot fire test pit and containers immediately following Fire Test 1 (D63-13152)

\section{Water-Submersion Tests}

The water-subnersion criterion has, with the exception of one test, been largely ignored, basically, because the development concept of this shipping container was an outer shell protecting an inner

\footnotetext{
3. E. Bader, Heat Transfer in Liquid Hydrocarbon Fuel Fires, Sandia Corporation Report SC-DR-320-63, February 1964.

2 Ibid.
} 
container from essentially all effects of shock and fire. If this is done, a water-tight seal on the inner container is a simple matter to maintain.

Designs Tested

A number of designs have been examined and found lacking because of high cost, limited application, or other reasons. A few designs that were subjected to test were as follows:

1. Steel container with a special gypsum insulation. This material is a very good insulator, but was difficult to fabricate because of drying probiems.

2. Steel container with a zonolite concrete insulation. This material was also difficult to fabricate and failed the fire test because of shrinking and cracking.

3. Wooden containers in cubical shapes. These containers were difficult to build strong enough to survive both the drop and fire tests.

A hollow cylindrical wooden shell was finally selected for encasing an ICC Type 55 or similar shielded container, thus protecting this inner container from the effects of shock and fire (Figures 2 and 3). The shell was constructed from rings of $3 / 4$ inch plywood which were glued together with a strong shock-resistant adhesive and reinforced with cement-coated nails. A full-length bolt ring was also used to add rigidity and to hold the lid (Figure 4). Both the bolts and the nails serve to prevent complete failure of the container if it is cracked in the drop test. For containers of several tons, some cracking is acceptable during the drop test so long as no serious separation of the wood plies takes place. A wall thickness of 4 inches of bare insulating material is necessary to survive a 1-hour fire, although a 3 -inch wall will survive a 1 -hour. fire if a protective sheet-steel outer covering (Figure 5) is used and internal temperatures of up to $500^{\circ} \mathrm{F}$ can be tolerated for the last 15 or 20 minutes of the fire. If the contents of the inner container are not to exceed $200^{\circ}$ to $220^{\circ} \mathrm{F}$ (i.e., when shipping liquids), a minimum of 6 inches of wood insulation is required.

There are times when requirements other than the fire test affect features of shell construction. Heavy or very dense containers require a thicker wall to survive a 30 -foot drop test. The large container in these development tests had 2 by 2 inch rings added (Figures 4 and 6). These rings have two purposes: to facilitate handling; and to absorb a significant portion of the energy of the drop, thus preventing the container wall from splitting (Figure 7). An important consideration in constructing al1 wooden-she11 containers is to assure that the lid joints of the inner container and the outer she11 are offset. Another construction feature worth consideration is the addition of a light sheet-metal shell ( 16 to 20 gage). This type of shell not only offers protection against routine shipping damage, but also protects against a fire environment by preventing the charred wood from sloughing off (Figure 8). However, when a steel shell is used, the shell must be vented to prevent pressure buildup by allowing combustion gases to escape. 


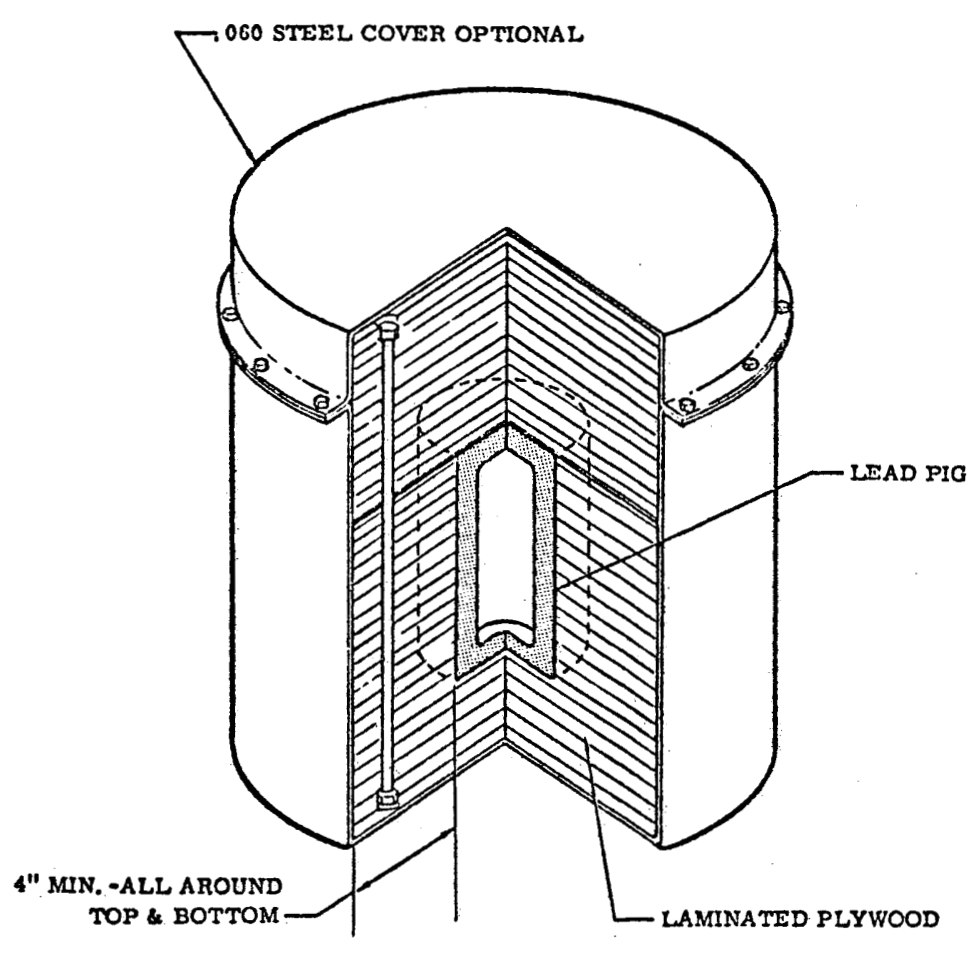

Figure 2. Cutaway view of the small wood insulated container with optional steel shell

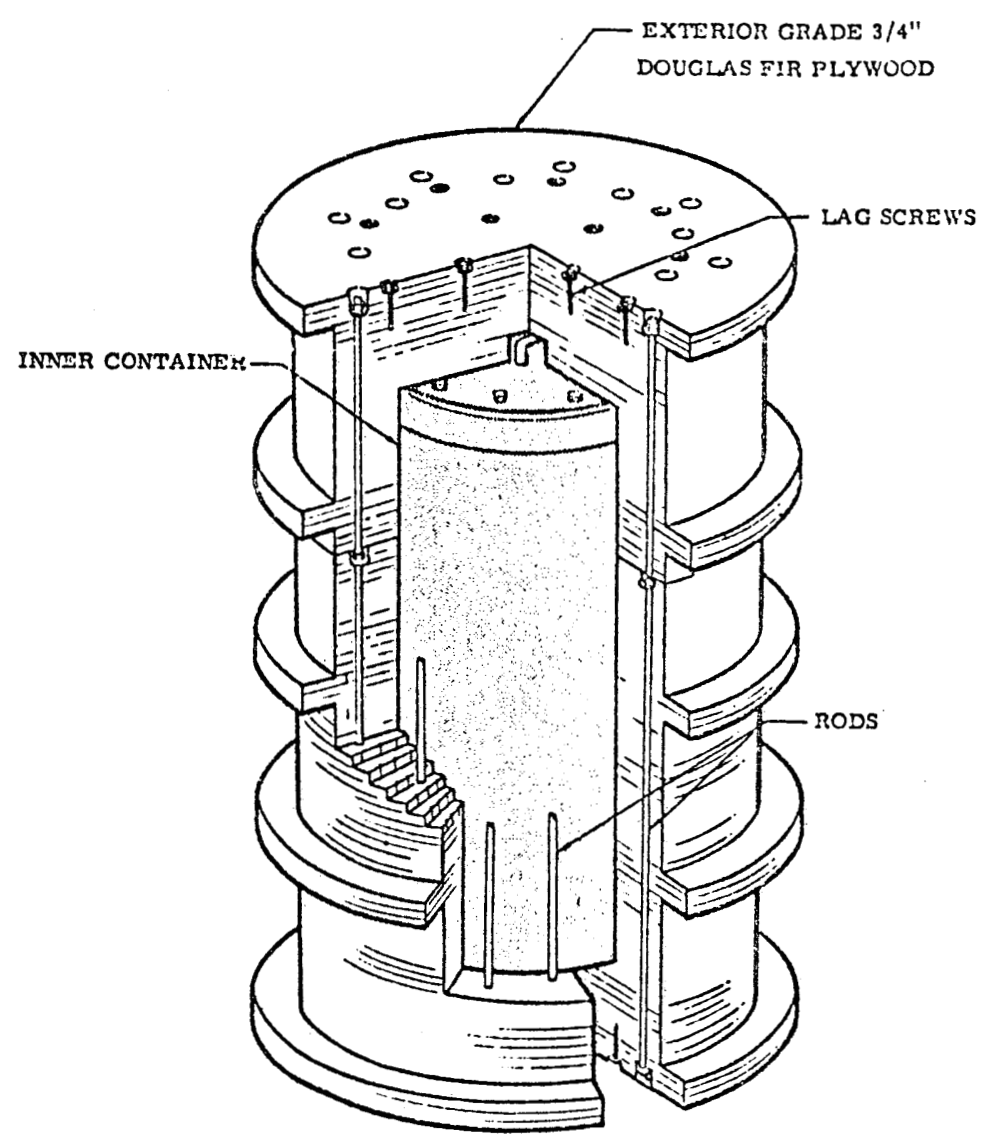

Eigure 3. Cutaway view of the 4000-pound container used in SC test and development program; It is representative of large containers in general 


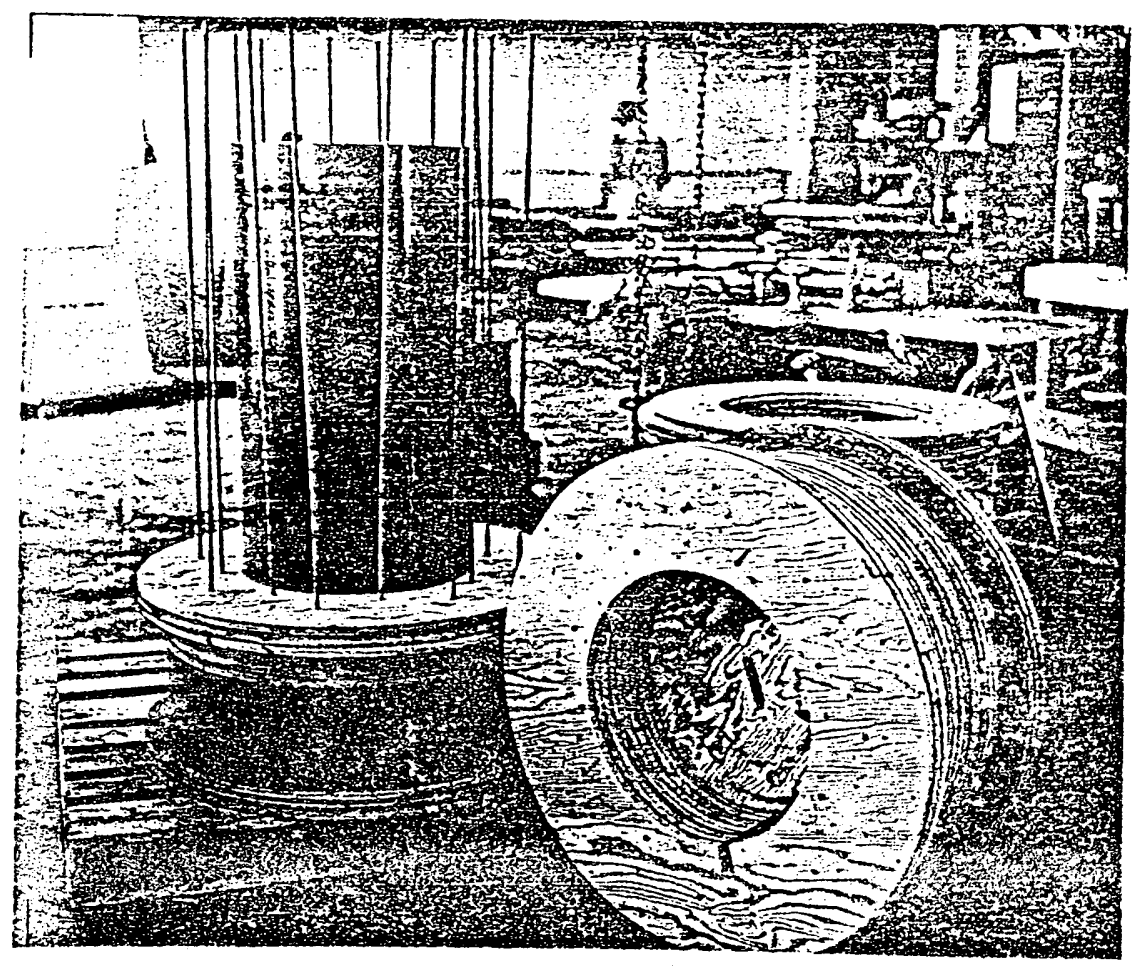

Figure 4. Construction of the 4000-1b container using an ICC-55 shielded inner container (D64-7921)

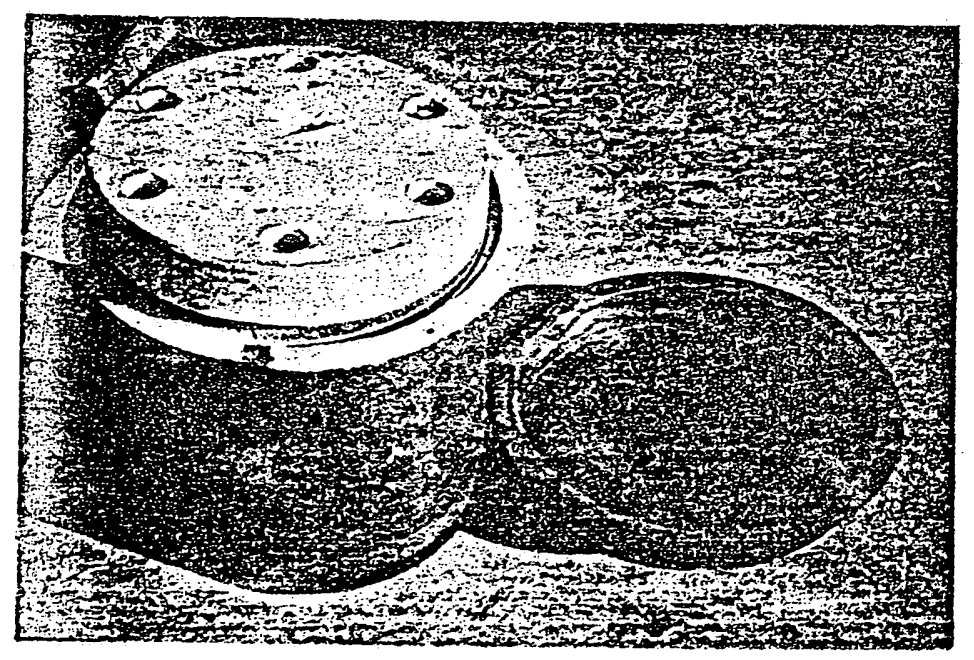

Figure 5. Small 3-inch wall container with steel shell (D63-13101) 


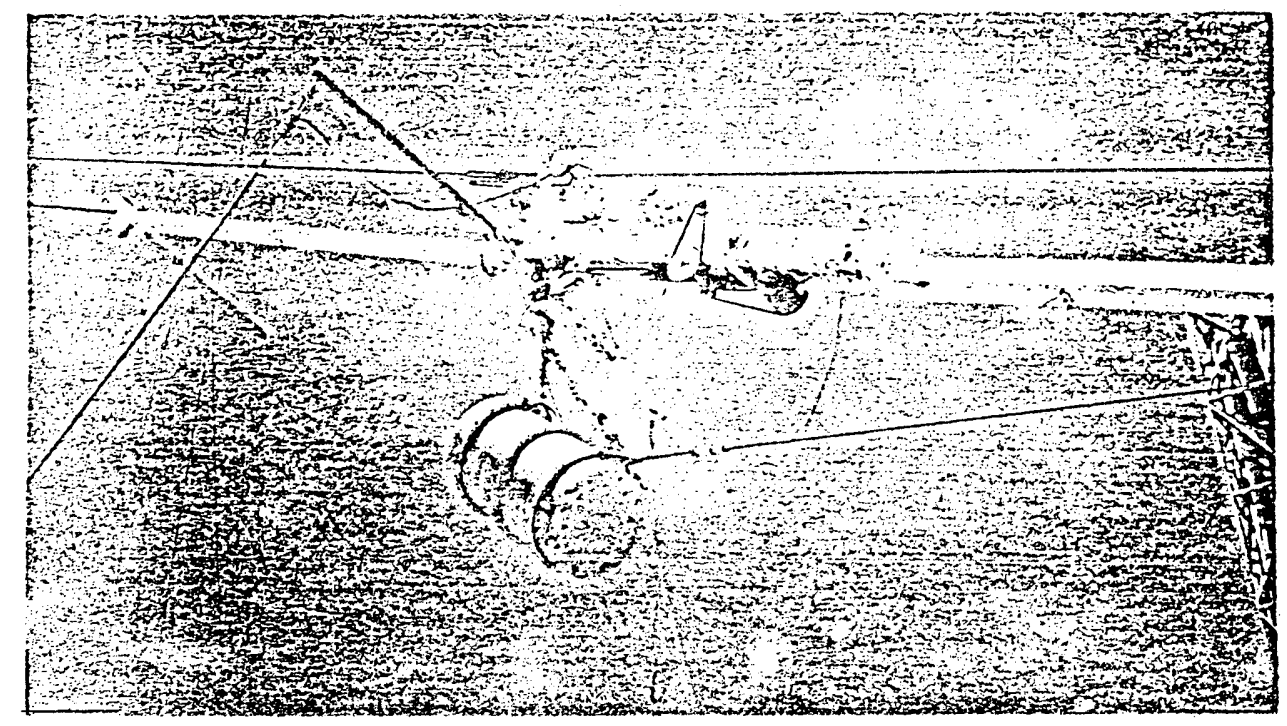

Figure 6. Urop test of second 4000-pound contairer (D64-9589)

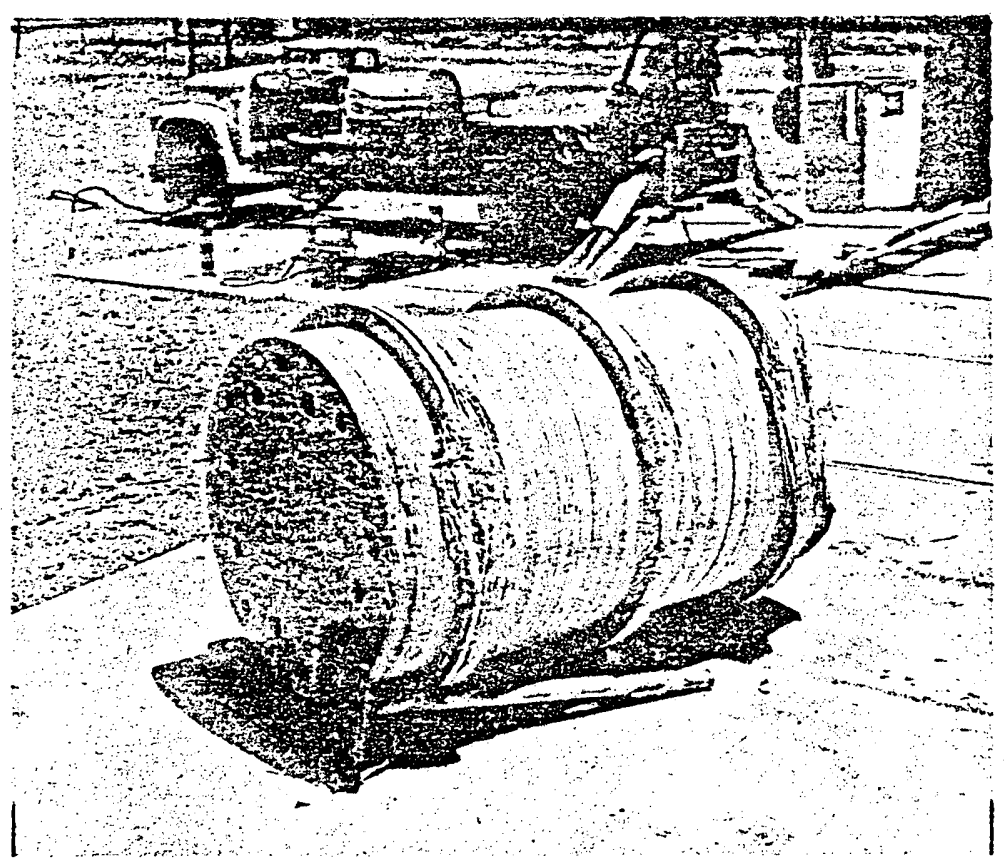

Figure 7. Effects of 45-degree angle drop test of 4000-pound container (D64-9588) 


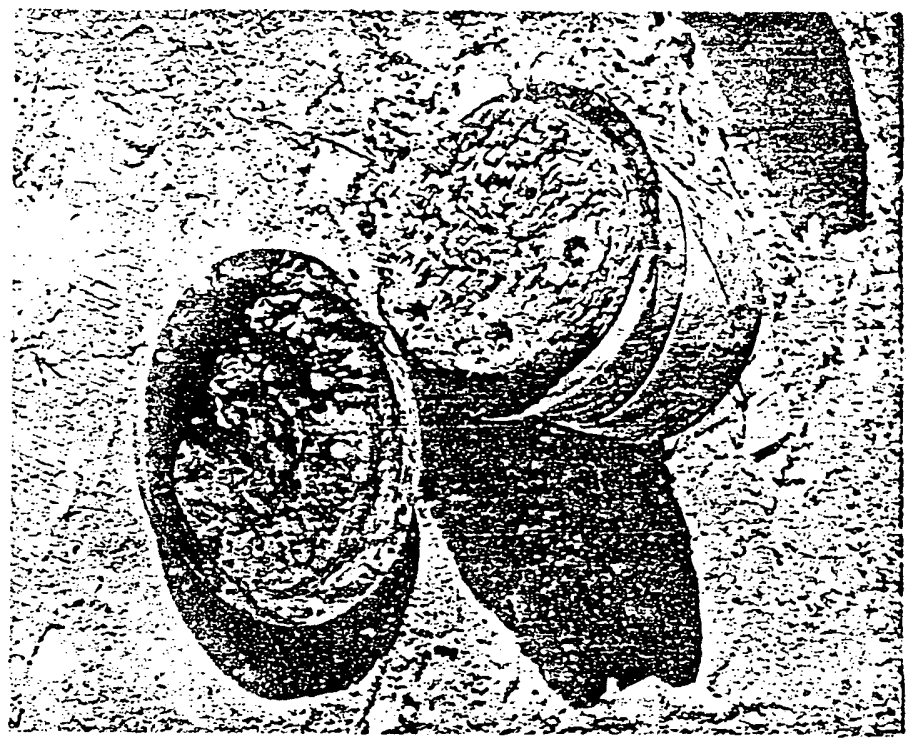

Figure 8, Small 3-inch wall container protected by steel shell showing char layer still intact after Fire Test 1--this container is constructed exactly as shown in Figure 2 (D63-13140)

Test Results

\section{Drop Tests}

A number of containers were built with various wall thicknesses and inner diameters. After consultation with several wood research laboratories, four types of materials were tried: Douglas-fir plywood and solid wood, and redwood plywood and solid wood. The Douglas-fir plywood proved to be the most satisfactory material. The solid woods have too great a tendency to split or crack.

The redwood plywood seems to exhibit this tendency to split or crack to a greater degree than the fir plywood, for larger highdensity container designs. For containers of 200 pounds gross weight or smaller, it is felt that redwood plywood would be satisfactory. In addition, there are obviously many other types of plywood, and perhaps some pressed-wood-fiber board, that would be equally as effective as Douglas-fir plywood for use in a wooden-shell design. It was not intended to evaluate all possible materials, but only to find one or two good ones that were cheap and readily available. 
A number of different adhesives were considered or tried. Resorcinol-formaldehyde, phenyl-formaldehyde, and polyvinyl acetate aqueous emulsion (white glue) appear to be some of the better ones. Each one has its limitations, however. Resorcinol-formaldehyde is a room-temperature curing, exterior grade glue that has high shear strength and strong bonding characteristics, but it must be cured under pressure (180-200 psi) to form a good bond. Phenyl-formaldehyde is an excellent exterior grade adhesive, but it must be cured under heat $\left(200^{\circ}-250^{\circ} \mathrm{F}\right)$ and is difficult to use in bonding very thick layers of wood. Polyvinyl-acetate aqueous emulsion (white "Elmers Glue" type) is the easiest to use, but it should be reinforced with cementcoated nails. It has very high shear strength under dynamic testing conditions but it is temperature and humidity sensitive to some extent and will "cold flow" if subjected to temperatures of $120^{\circ} \mathrm{F}$ or higher. These characteristics did no: appear to be a problem for the Sandia wood-insulation designs because of the reinforcement provided by the cement-coated nails, the full length bolt ring, and the rigidity of the inner metal pig. This combination of adhesive and construction survived the testing program extremely well under the moderately warm and dry desert conditions prevalent in the Albuquerque area, but it would need clcse examination for use in very large and massive shells being designed for use in the tropics. The ideal construction techniques would utilize a resorcinol-formaldehyde adhesive bonded under pressure and reinforced with cement-coated nails. The use of a full length bolt ring to keep the lid in place is always assumed in this papex. This bolt ring contxibutes to the stiffness of the shell and helps, with the nails, to prevent a catastrophic failure if some delamination of the plywood takes place as a result of an impact.

The largest container built in this series consists of a 3275pound ICC-55 steel-lead-steel cylinder encased in a 6-inch-thick plywood shel1 (Figure 4) with 2 by-2-inch cushioning rings added. The gross weight of this container is 4000 pounds.

Five or more cushioning rings are suggested for containers weighing over 2000 pounds, one cushioning ring layer at each end and three more evenly spaced between. This would make the end caps 8 inches instead of 6 inches thick. As a result of this added thickness, no harm is done if one of the end rings shears off entirely during a drop test.

Ten 30-foot drop tests have been made to date of the 4000-pound container. Eight units have been dropped; one was dropped three times (one end, on the side, and at 45 degrees on opposite end), accounting for the extra two drops. All containers survived in suitable condition to withstand a 1-hour petroleum fire without repair. The first test unit, utilizing resorcinol-formaldehyde glue, experienced some glue-joint failure, but this condition was corrected in subsequent drops. One 4000-pound container was drop tested following a 1-hour petroleum fire and survived without damage to the inner pig. Three drop tests were of resorcinol-formaldehyde-bonded (no nails used except in end rings), fir-plywood-shel1 designs. One of the drops took place during the International Symposium. Although there was slightly more delamination evident in this construction than in the nail-reinforced design, there was no damage that would affect the subsequent fire response of the container. It should be mentioned at this time that any wood-insulation design that utilizes an exterior metal she11 should not require the use of reinforcing nails in the construction. 
A number of smaller containers, ranging in size from 25 to 200 pounds, were dropped from 30 feet and were not noticeably damaged. Most of these were dropped three times (one end, side, and at 45 degrees) in an attempt to detect differences in response. Even with three drops, damage to this size range of container was only superficial,

A tabulation of the drops will be found in Appendix A.

\section{Fire Tests}

The results of the first fire test (see Appendix B) were most favorable for the wooden containers. Before the fire test, both the 3 -inch and 6 -inch wall models survived three drop tests each, while ballasted with a 61-pound steel billet simulating an inner container. The containers were then subjected to the 1-hour petroleum fire at $1850^{\circ} \mathrm{F}$. Although there were difficulties with the thermocouple leads, other backup data indicate that the interior temperature in the 6-inch wall container could not have exceeded $300^{\circ} \mathrm{F}$ and probably was under $150^{\circ} \mathrm{F}$ (Figure 9). The 3-inch wall, steel jacketed, container had 1 inch of good wood left surrounding the inner billet and temperatures were in the $400^{\circ}$ to $500^{\circ} \mathrm{F}$ range, according to the best estimates based on other test results.

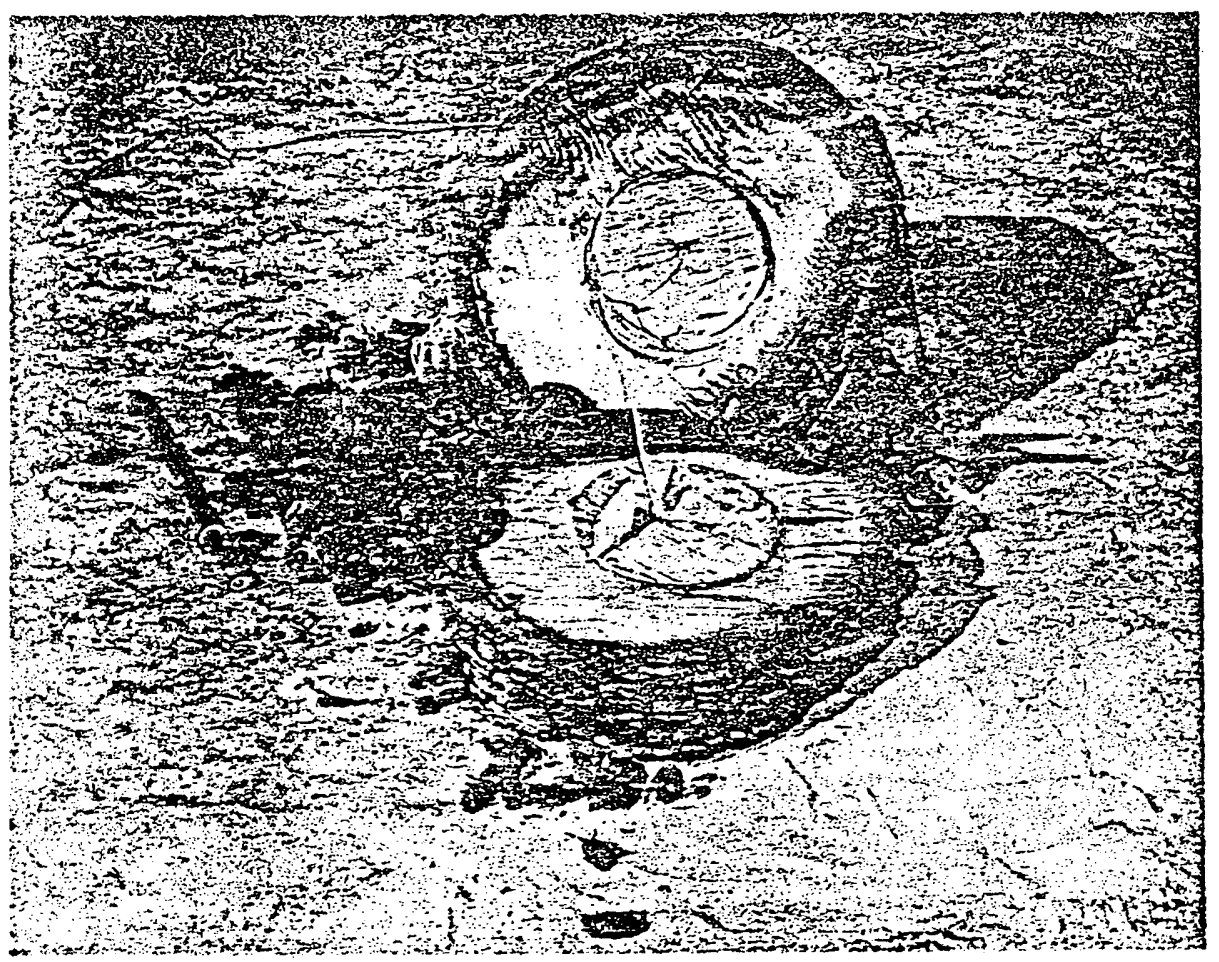

Figure 9. 6-inch wall Douglas-fir plywood unprotected container after Fire Test 1 showing amount of undamaged wood (D63-13141) 
Following the first fire test and the excellent performance of wood, an investigation was begun into the thermal insulation properties of several types that were of most interest due to cost and other considerations. The Sandia Corporation Radiant Heat Facility was utilized to supply a simulated fire environment that could be carefully controlled over small areas. Four $8 \times 8 \times 6$-inch thick blocks were made up with small thermocouples imbedded at $1 / 2$-inch intervals all the way through the 6-inch thickness (Figure 10). A quartz lamp radiant heat panel was programed to provide an $1850^{\circ} \mathrm{F}$ black-body radiant heat source (a heat rate of $11 \mathrm{BTU} / \mathrm{ft}^{2}-\varepsilon$ ec was actually measured) for 1 hour for each of the four blocks. Sample blocks tested were:

1. Douglas-fir plywood exterior grade, $3 / 4$ inch thick, laminated into a single 6-inch thick block.

2. Douglas-fir lumber, nominal 2 inches thick, laminated into a single 6 -inch thick block.

3. Redwood plywood, exterior grade, $3 / 4$ inch thick, laminated into a single 6-inch thick block.

4. Redwood lumber, nominal 2 inches thick, laminated into a single 6 -inch thick block.

The plywood blocks were tested so that the heat source was exposed to the maximum end grain. In the solid-wood blocks end grain was 90 degrees to the heat source. For the actual curves obtained from this test series see Appendix C. As can be determined from the curves the solid-wood blocks performed best with plywood blocks close behind. The redwood plywood made the poorest showing. Figure 11 showing the blocks after the tests reveal two things; namely, the char rate in the radiant heat test was twice what it was in an actual fire (it jumped from 2 inches in a fire to 4 inches in the radiant heat test), and there was a definite tendency for the heat to travel down the glue joints. The adhesive used in laminating the blocks was polyvinylacetate aqueous emulsion (white glue) fabricated under "box shop" conditions. The resorcinol-formaldehyde used in the fabrication of the plywood did not exhibit such tendencies. It is rather unusual that excessive heat travel, down the glue joints, had not been detected in actual fire tests. It is believed both of the above anomalies can be explained by the strong air blast applied to the face of each block during the test. This air blast is necessary to cool the radiant panel quartz lamps and causes no problem on nonflanmable materials. An effort is now underway to construct an analytical model of the heat flow through a wood block from an $1850^{\circ} \mathrm{F}$ black-body radiant source. 


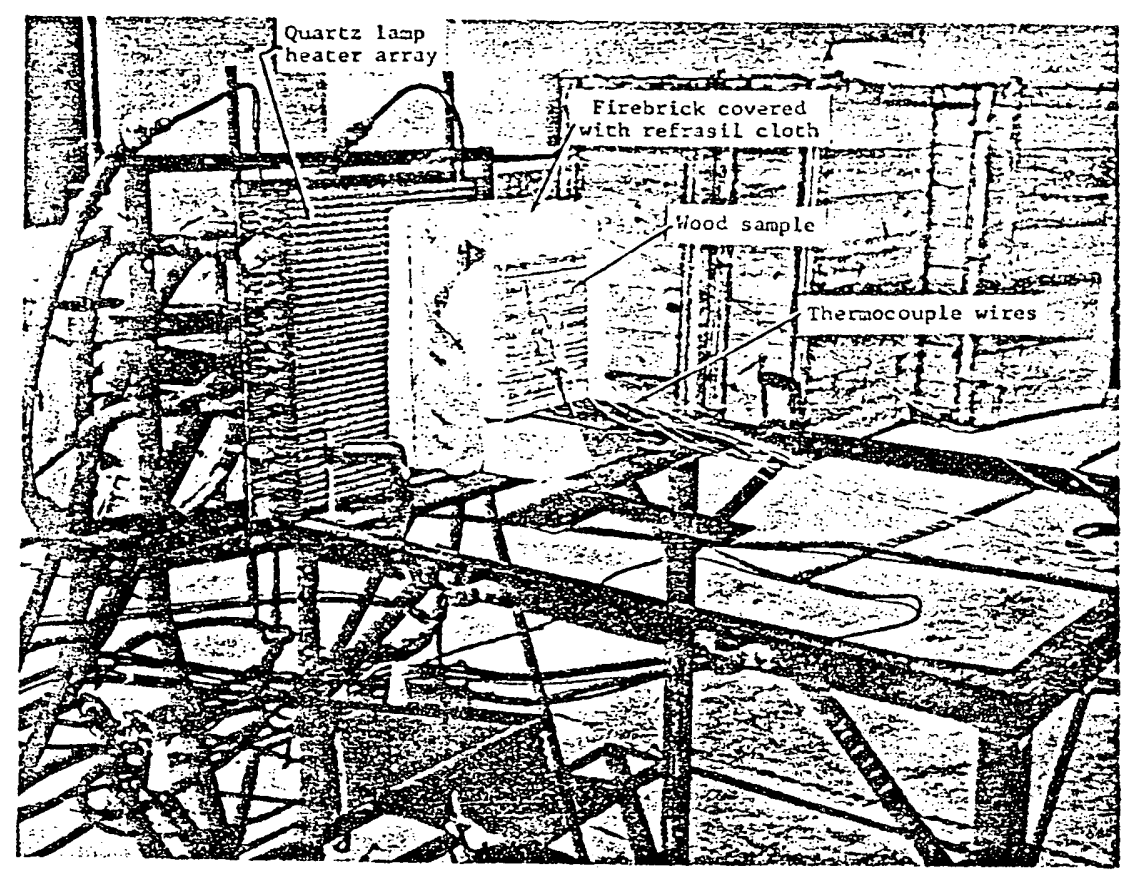

Figure 10. Test setup; radiant heat test of four wood panels (D64-2524)

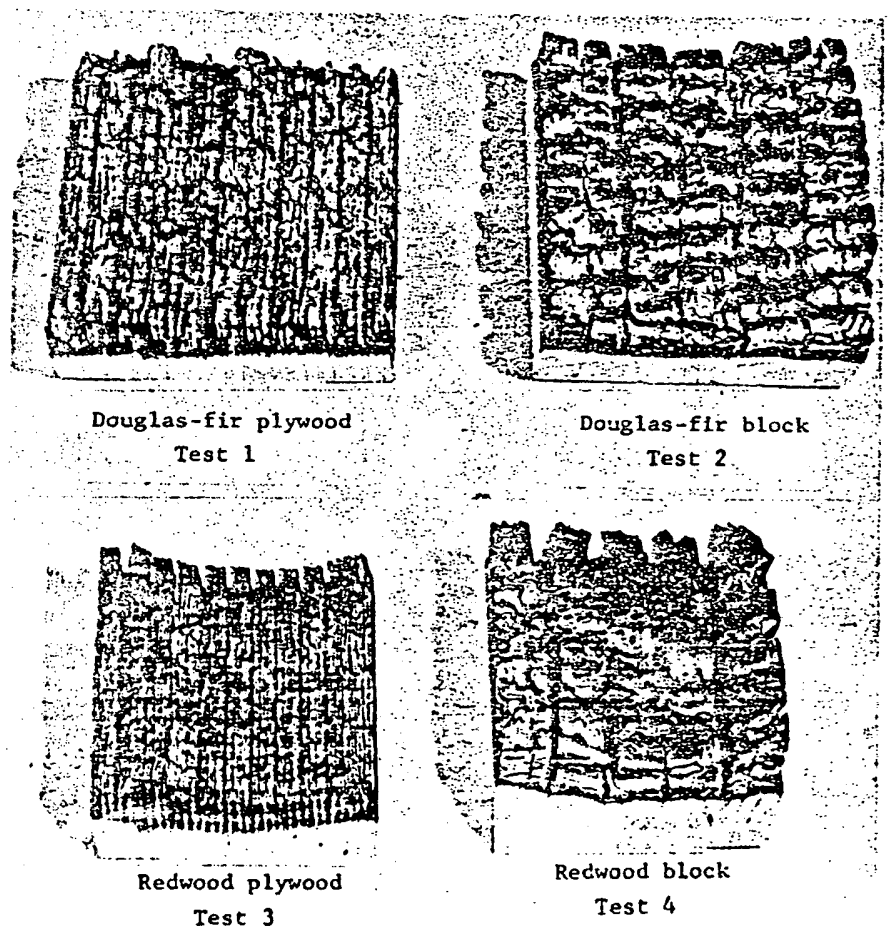

Figure 11.

Appearance of four wood panel after radiant heat test simulating a 1 hour fire (D64-2519) 
The second open-pit fire test was similar to the first test, except a $30 \times 30$-foot pit was used instead of a $20 \times 20$-foot.pit (Figure 12) i Eleven instrumented containers were tested (see Appendix B) for 1 hour; 9880 gallons of JP-4 fuel were used, producing the hottest fire in the test series. Some of the high-temperature fiberglass insulation on the thermocouples disintegrated causing shorts. Carbon impregnation of the thermocouple insulation also caused shorts. With partial failure of the thermocouples (which had been successfully used in dozens of other Sandia fire tests) in two fire tests, it was decided to change to stainless-steel sheathed thermocouples in future tests for container instrumentation. Seven of the eleven test objects in Fire Test 2 survived. It had been anticipated that $t w o$ of the containers would fail, since wall thickness was very minimal. The other two failures were the solid redwood containers which apparently split and burned quite rapidly. The solid Douglas fir also split and cracked, but still survived (Figure 13).

Fire Tests 3, 4, and 5 (see Appendix B) confirmed conclusions drawn earlier regarding the superior perfcmance of fir plywood laminated shells in protecting an inner ICC -55 or similar container from the rigors of a severe accident.

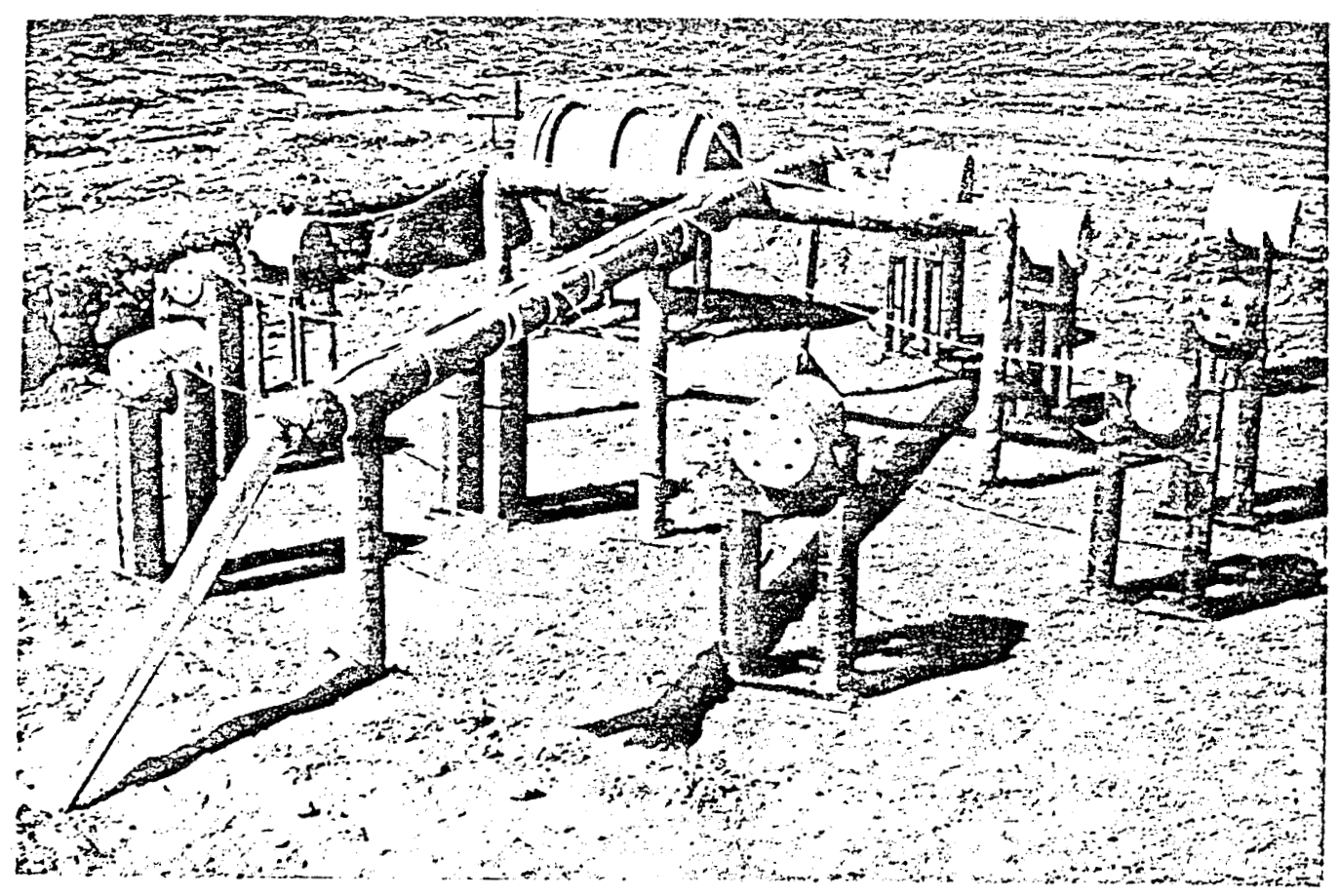

Figure 12. Test array in $30 \times 30$-foot pit for Fire Test $2(D 64-10016)$ 


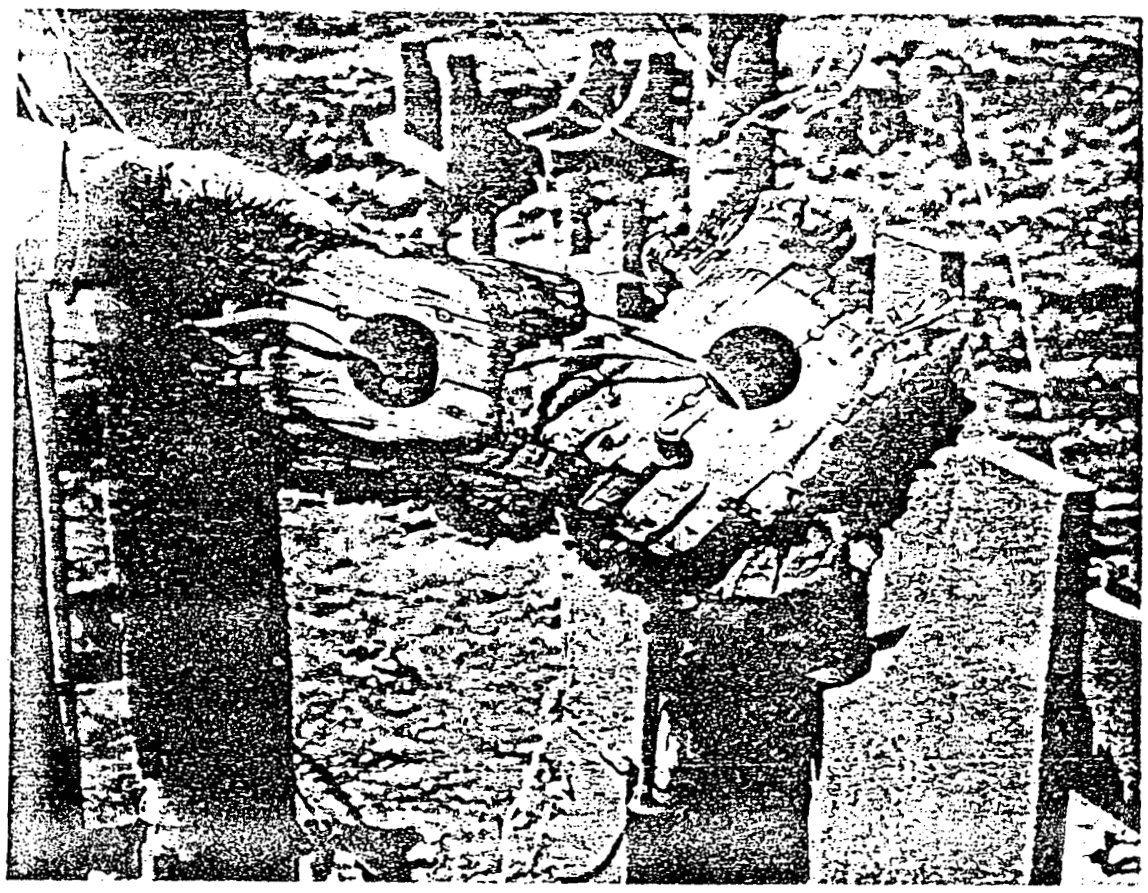

Figure 13. Solid Douglas fir, 4-inch thick wall cylinder showing splitting found to be characteristic of solid wood containers (D64-2616)

\section{Conclusions}

The purpose of this study and test effort was to develop a container, for shipping radioactive materials, capable of withstanding the fire and drop test outlined in the proposed regulations.

A laminated plywood shell with a 4-inch minimum wall thickness will provide the necessary protection for an approved ICC inner container against the I-hour fire environment. However, thicker wood shells may be required for shipment of low-boiling-point liquids. The weight and structural features of the inner container may require a thicker wood shell to survive the drop-test requirements and to ensure that 4 inches of wood surround the container after the drop tests. However, in providing a protective shell for massive containers that contain no liquids or other pressure generating materials that might escape when exposed to temperatures under $500^{\circ} \mathrm{F}$, it would not always be necessary for the protective shell to stay completely intact. At least 10 to 15 percent of the outer surface area of most large containers could be exposed to a fire environment for 1 hour and still not be in danger of loss of shielding. Therefore, for some shipping 
container designs the requirement that the outer protective shell remain 100-percent intact during the 30-foot drop could be relaxed to something more practical.

The early development work for the wooden-shell insulation concept has indicated that the following conditions appear to be true:

1. There is no significant difference in the burn rate between Douglas-fir and redwood plywood; however, redwood seems to incur a greater amount of splitting that could be detrimental in the fire environment.

2. There is no significant difference in the temperature gradient or char rate that can be verified for these two plywoods.

3. Plywood is superior to solid woods because of the tendency of the solid woods to split in the fire environment.

4. A glued and nailed laminate with through bolts for lid closure will produce a container that will survive the drop tests.

Although additional research must be done to refine existing data and establish concise design critexia, sufficient information is available to design an effective, economical container which will meet the rigorous requirements of the regulatory agencies. 
APPENDIX C

APPROVAL DOCUMENTS 

DOE FOrI, EV-618

10 CFR?
U.S. DEPARTMENT OF ENERGY CERTIFICATE OF COMPLIANCE

For Aadioactive Materials Packages

\begin{tabular}{|c|c|c|c|c|c|}
\hline \multicolumn{2}{|c|}{$\begin{array}{l}\text { 1a. Certificate Number } \\
9856\end{array}$} & $\begin{array}{l}\text { 1b. Revision No. } \\
0\end{array}$ & $\begin{array}{l}\text { 1c. Package Identification No. } \\
\text { USA/9856/BL(DOE-OR) }\end{array}$ & $\begin{array}{l}\text { 1d. Page No. } \\
1\end{array}$ & 1e. Total No. Pages. \\
\hline \multicolumn{6}{|c|}{ 2. PREAMBLE } \\
\hline $2 a$. & \multicolumn{5}{|c|}{$\begin{array}{l}\text { This certificate is issued to satisfy Sections 173.393a, 173.394, 173.395, and } 173.396 \text { of the Department of Transportation Hazardous } \\
\text { Materials Regulations ( } 49 \text { CFR 170-189). }\end{array}$} \\
\hline $2 b$. & \multicolumn{5}{|c|}{$\begin{array}{l}\text { The packaging and contents described in item } 5 \text { below, meets the safety standards set forth in Subpart C of Title } 10, \text { Code of Federal } \\
\text { Regulations. Part } 71 \text {, "Packaging of Radioactive Material for Transport and Transportation of Radioactive Material Under Cartain } \\
\text { Conditions." }\end{array}$} \\
\hline $2 c$. & \multicolumn{5}{|c|}{$\begin{array}{l}\text { This certificate does not relieve the consignor from compliance with anv requirement of the regulations of the U.S. Department of } \\
\text { Transportation or other applicable regulatory agencies, including the government of any country through or into which the package } \\
\text { will be transported. }\end{array}$} \\
\hline
\end{tabular}

3. This certificate is issued on the basis of a safety analysis report of the package design or application-

(1) Prepared by (Name and address):

Oak Ridge National Laboratory

P.O. Box X

Oak Ridge, TN 37830
(2) Title and Identification of report or application:

(3) Date:

Safety Analysis Report for

Packaging: The ORNL DOT

Specification 20-WC-5-

Special Form Packaging

4. CONDITIONS

This certificate is conditional upon the fulfilling of the requirements of Subpart $D$ of 10 CFR 71, as applicable, and the conditions specified in item 5 below.

5. Description of Packaging and Authorized Contents, Model Number, Fissile Class, Other Conditions, and References:

a. Packaging

(1) Model No.: DOT 20 WC-5 - Special Form

(2) Description: Wooden protective jacket as described and constructed in accordance with DOT 20-WC (49 CFR 178.194) with a single inner packaging consisting of a lead shield encased in series 300 stainless steel and

b. Contents: conforming to DOT 7A (49 CFR 178.352).

(1) Type and Form of Materia1:

(a) Nonfissile, solid radioactive materials.

(b) Radioactive material is encapsulated in a metal capsule meeting the special form definitions of:

1 U.S. Department of Transportation Regulations, 49 CFR 173.389(g), and

2 International Atomic Energy Agency Safety Series No. 6, Regulations for the Safe Transport of Radioactive Materials, 1973 Revised Edition (As Amended), Part 135.

\begin{tabular}{|c|c|}
\hline January 7, 1983 & January 6,1988 \\
\hline \multicolumn{2}{|c|}{ FOR THE U.S. DEPARTMENT OF ENERGY } \\
\hline $\begin{array}{l}\text { 7a. Address lof DOE Issuing Officel } \\
\text { U.S. Department of Energy } \\
\text { P.O. Box E } \\
\text { Oak Ridge, TN } 37830\end{array}$ & $\begin{array}{l}\text { 76. Signature, Name, and Title lof DOE Approving Officiall } \\
\text { Williem A Trames } \\
\text { William H. Travis, Director } \\
\text { Safety \& Environmental Control Division }\end{array}$ \\
\hline
\end{tabular}


Certificate No. 9856, Rev. $0 \quad-2-$

Capsules are individually leak tested during fabrication per ANSI N542, procedure A2.2.1 (ethylene glycol-vacuum technique) or equivalent.

(2) Maximum quantity of material per package:

The maximu quantity of radioactive material is a large quantity for special form which is limited to:

(a) Up to 100 watts of thermal decay energy, and

(b) The authorized external radiation levels specified with the regulations of the U.S. Department of Transportation 49 CFR 173.393(j). 
UNION

GARBIDE
NUCLEAR DIVISION

TC $82-2$

INTEAAA! CORBESPONDEACE

To: R. W. Schaich

From: $\quad$ E. M. King

Subject: Approval of Safety Analysis Report for Packaging: The ORNL DOT Specification 20WC-5-Special Form Package

The Transportation Committee has reviewed your submission dated April 22, 1982. The 20WC outer protective jacket, the inner Type A packaging, and the certified Special Form encapsulation were reviewed。

The review concludes that the container provides for the safe shipment of the materials listed in the IAEA Certificates of Competent Authority as included in your submission.

\section{E.M. King}

E. M. King, ohairman

Transportation Committee

cc: G。H. Burger 


\title{
INTRA-LABORATORY CORRESPONDENCE \\ OAK RIDGE NATIONAL LABORATORY
}

June 24, 1982

\author{
To: \\ From: \\ E. Lagb \\ $\operatorname{lin}$ \\ K. W. Haff and B. P. Phillips \\ Subject: Type A Drop Test on ORNL Radioisotope Shipping Cask \\ (ORNL Drawing X3D-10191 109)
}

The ORNL Sugarman Cask described on ORNL Drawing X3D-10191 109 was dropped to test conformance to Type A packaging requirements (49CFR $173.398(\mathrm{~b})$ ) on June 2, 1982 .

The cask before the drop is shown in the attached photograph (ORNL Photo No. 93393). The cask suffered minimal damage as a result of the $4 \mathrm{ft}$ drop test. The attached photographs (ORNL Photo Nos. 2237-82, 2236-82, and 2235-82) show that no damage serious enough to impair shielding or containment of radioactive material occurred as a result of the drop test.

The cask has demonstrated its ability to withstand the rigors of transportation and the other tests required by 49CFR 173.398(b) through greater than ten years of actual service. I, therefore, conclude that the ORNL Radioisotope Shipping Cask meets the requirements for Type A packaging.

$\mathrm{KWH}: \mathrm{drW}$

Attachments

cc: F. N. Case

C. L. Ottinger

J. E. Ratledge

R. W. Schaich 
APPENDIX D

ROUTINE PACKING AND INSPECTION PROCEDURES 


\section{OPERATIONS DIVISION RADIOISOTOPE DEPARTMENT BUILDING 3038}

RHDIOISOTOPE PACKING AND SHIPPING

OAK RIDGE NATIONAL LABORITORY

RADIOISOTOPE PACKAGINC AND SHIPPING PROCEDURE

PROCEDURE FOR APPROVAL TO SHIP RADIOACTIVE MATERIAL

1. All requests to ship radioactive material are first referred to the SS Mazerials Management Department or to the Isotopes Sales Office for approval [reference: Isotopes Sales Operatirg lianul and the luclean Haterials Management Manual, ORNL-2800 (Revised)].

2. Radioactive Materials Packaging Form (UCN-12301) is completed by the requester and attached to the Special Works data sheet (UCN-1784) or the SS Accountability document (UCN-2681). The supervisor of the Radioisotope Packing and Shipping operation reviews the information provided and flags all shipping documents for shipments requiring Type " $B$ " shipping containers.

3. Documentation of requests for shipping radioactive materials with half-lives $>14$ days is submitted two full working days before the scheduled shipping date to give adequate time for review of package documentation and approval of the shipment.

4. Documentation of requests for shipment of radioactive material with a half-life of <14 days must be submitted by 1:00 p.m. on the day before the scheduled shipping date.

5. The review of packaging documentation follows the procedure established in ORNL Guide for the Packaging of Radioactive Materials for Transport, and Nuclear Materials Management Hanual, ORNL-2800 (Revised).

6. A Radioactive Materials Packaging Form (UCN-12301) is required for all returnable container shipments (empty or full) and for all shipments containing $>1 \mathrm{mCi}$ alpha or $>3 \mathrm{Ci}$ beta/gamma.

\section{PACKING AND SHIPPING PROCEDURE}

1. The supervisor of the Radioisotope Packing and Shipping Operation (RPSO) receives approved shipping documents UCN-2775 (3 3-79) from the SS Materials Management and Isotopes Sales Group by 1:00 p.m. on the day before the shipment is scheduled to leave ORNL.

2. The RPSO supervisor reviews each shipping document and the Radioactive Materials Packaging Form and reports any discrepancies to the Process Group Leader for action. In the absence of the Group Leader, discrepancies in the documentation are reported to the Radioisotope Department Superintendent for action.

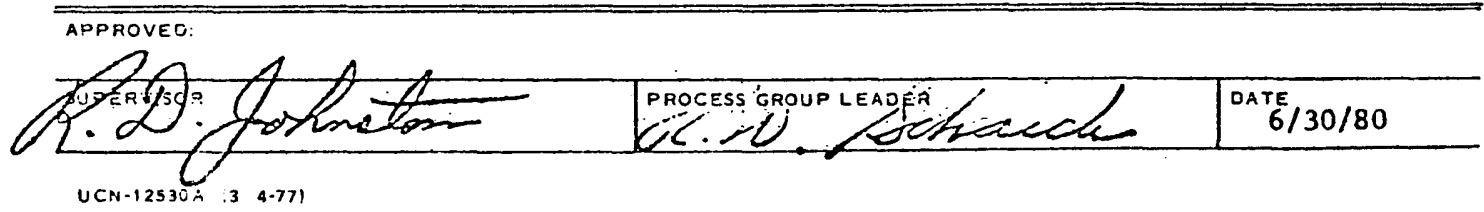




\section{OPERATIONS DIVISION RADIOISOTOPE DEPARTMENT}

RADIOLSOTOPE PACKING AND SHIPPTNC

OAK RIDGE NATIONLL LABORATORY

RADIOISOTOPE PACEACING AND SHTPPING PROCEDURE

3. All shipping documents flagged as Type "B" are separated by the RPSO supervisor and handled $c n$ a personal basis until the unit is properly loaded on the transporting vehicle. He then signs the Radioactive Naterials Packaging Form (UCN-12301) and imediately returns all completed documents to the Process Group Leader for a final review.

4. In the absence of the RPSO supervisor, the relief supervisor brings all shipping documents to the Process Group Leader for review and identification of shipments that require special attention of the relief supervisor.

\section{GENERAL REGULATIONS}

1. Short half-life materials ( $<14$ days) are shipped on Tuesday and Friday of each week. Special schedules can be arranged for holiday weeks. Medical isotopes are shipped when required.

2. Long half-life materials ( $>14$ days) are shipped on Wednesday and Thursday of each week. Shipments weighing greater than $300 \mathrm{lb}$ are shipped on Friday unless special arrangements are made.

3. All packages received at Building 3038 Packing and Shipping Room must meet ORNL Health Physics Manual Chapter 4.2 requirements concerning internal transfers of radioactive materials and must meet DOT shipping regulations for exgernal radiation ( $<200 \mathrm{mrem} / \mathrm{hr}$ at the surface and $10 \mathrm{mrem} / \mathrm{hr}$ at 3 feet). The RPSO supervisor must be notified by the originator of the shipment when he delivers his package to Building 3038 .

4. For each package, bottle of product, source, target, or other form of radioactive material taken to Radioisotope Packing and Shipping, a copy of the Special Work Order or a note must be attached to the container with the following information:

A. Quantity of radioactivity actually being shipped.1

B. Chemical form.

C. Concentration of radionuclide in solution, $\mathrm{mCi} / \mathrm{ml}$.

D. Volume or product weight.

E. Specific activity" (1ist as "C.F." for carrier free where applicable).

F. Assay date and time. 1

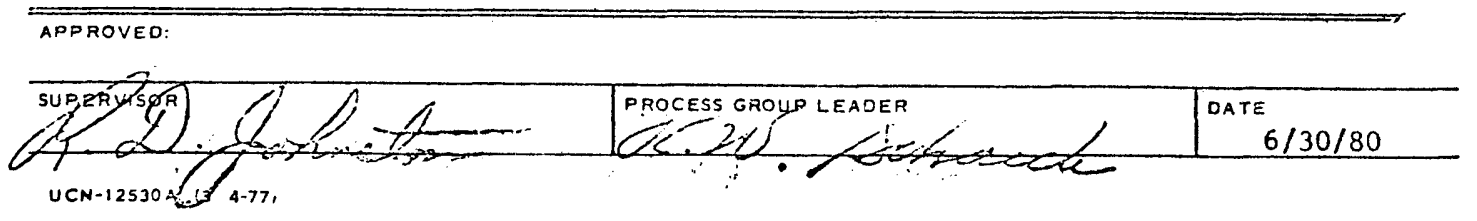




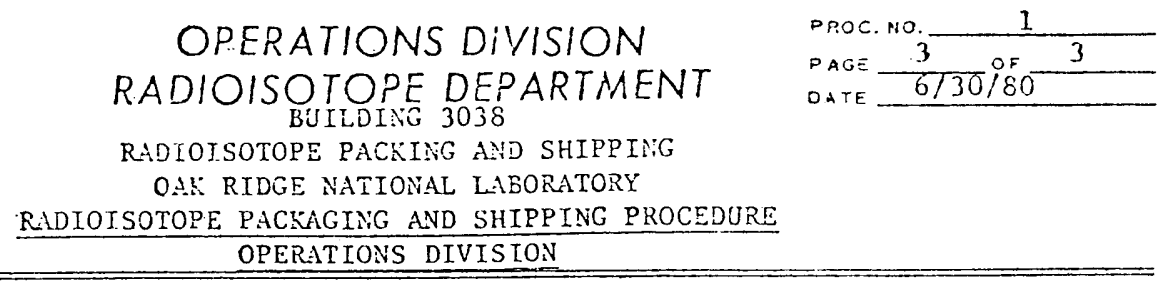

G. Normality of solutions of acids and bases.

H. Radiochemical purity. 2

${ }^{1}$ Unprocessed reactor and cyclotron targets are not assayed; therefore, quantity of radioactivity is calculated in these cases. Cyclotron target strip solutions should be analyzed for quantity of product radioisotope prior to shipment.

${ }^{2}$ In the case of short-lived radioisotopes, radiochemical purity assay results may be furnished after the shipment is made.

In the case of partial shipments of products listed on the Special Work Order a copy of the Special Work Order must be furnished with each partial shipment, and the items on the Special Work Order not being shipped must be marked out.

An Isotope Product Card (UCN-6216) must be filled out for every radioisotope product solution. In the case of product solutions loaded in shipping containers outside of Radioisotope Packing and Shipping, a completed copy of this form must be submitted with the product container to the packing Supervisor with a copy to the Isotopes Sales office.

5. The packaging and shipment of radioisotopes shall follow the Procedures for Packaging and Shipment of Radioactive Materials Building 3038 and ORNL Guide for the Packaging of Radioactive Materials for Transport.

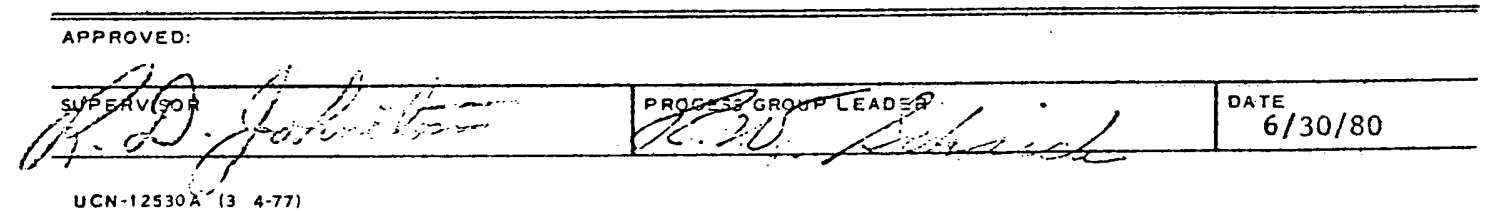




\section{OAK RIDGE NATIONAL LABORATORY RADIOACTIVE MATERIALS PACKAGING CERTIFICATION}

THIS FORM IS REQUIRED FOR ALL RADIOACTIVE SHIPMENTS AND ALL EMPTY RETURNABLE CONTAINERS

(Routine Type A Shipments Packaged by Process Group Personnel are Exempt)

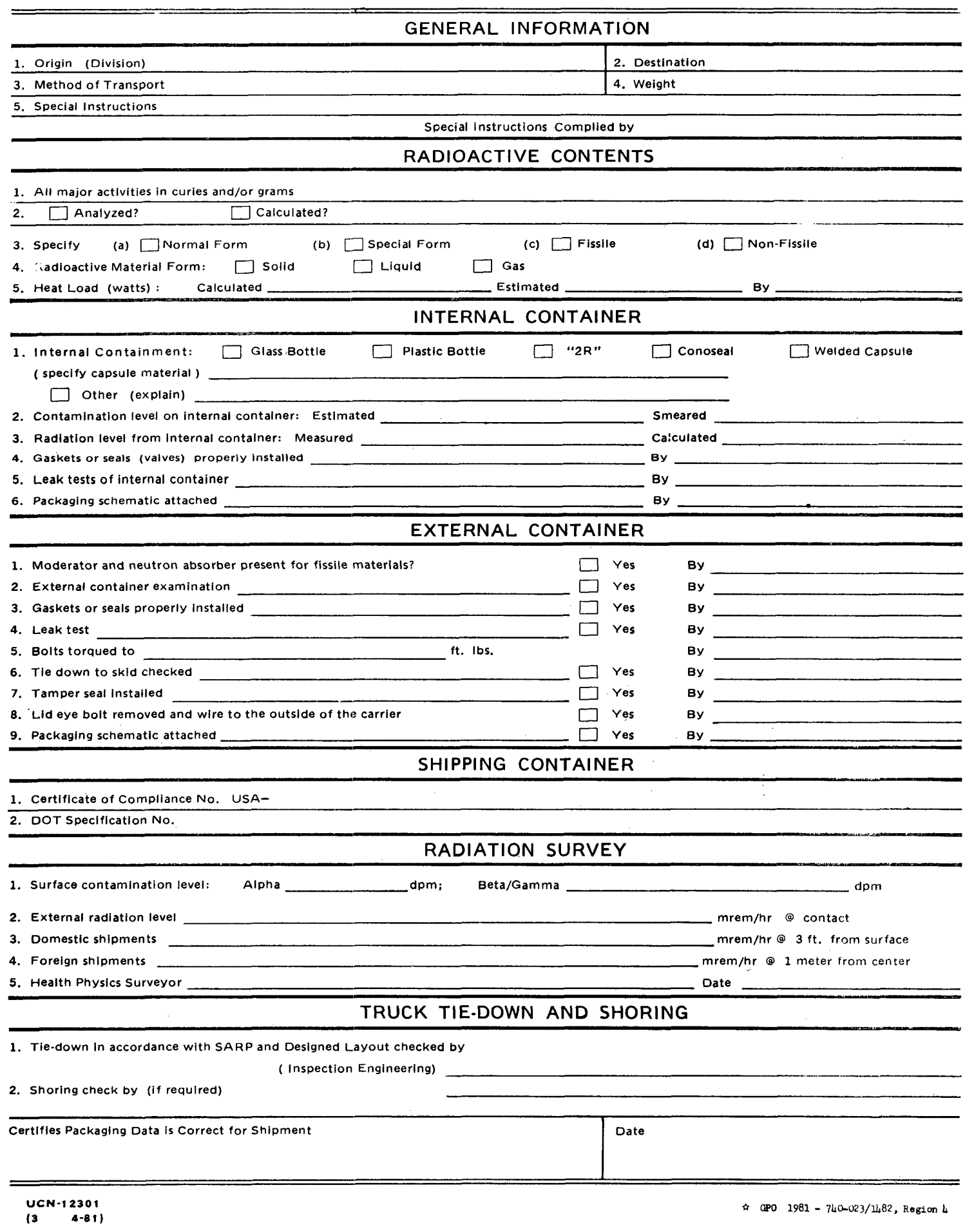




\title{
OPERATIONS DIVISION RADIOISOTOPE DEPARTMENT BUILDING 3029 \\ SOURCE DEVELOPNENT LABORATORY \\ QUALITY ASSURANCE PROCEDURE FOR TYPE B SHIPPING CONTAINERS
}

\author{
Incoming Type B Containers
}

1. Container is opened under the supervision of the Packing Foreman and a representative of the Health Physics Division. Radiation readings and smear levels on the external and internal surfaces are recorded. These records are stored in the auditable Quality Assurance (QA) file in Building 3029.

2. If container is contaminated externally or internally, it is cleaned to ORNL smear tolerance of $500 \mathrm{dis} / \mathrm{min}$ beta-gamma or $30 \mathrm{dis} / \mathrm{min}$ alpha. The final smear level is recorded by Health Physics and placed in the container's QA file.

3. If the radiation level internally or externally is greater than $1 \mathrm{mr} / \mathrm{hr}$ beta-gamna or $500 \mathrm{dis} / \mathrm{min}$ alpha, the container is to be decontaminated to the above tolerance. If decontamination efforts fail, the container is tagged out of service and the Department Head is notified in writing of the status. A copy of the notification is placed in the container's QA file. EXCEPTION: Uranium carriers may read up to $10 \mathrm{mrem} / \mathrm{hr}$ internally or externally.

4. Fire Shields

The RSPO Foreman will visually inspect all fire shields for cracks in the wood, protective coatings, foam glass, and/or steel covers. Defects in these items are to be recorded in the container's QA file and a blanket work order issued immediately to repair same. A copy of the blanket work order and the copy of the completed work order are to be placed in the container's QA file. An inspection of the repair work is to be made by the RSPO Foreman and a record of acceptance placed in the container's QA file.

Outgoing Type B Containers

1. Shielded Containers

a. A soap bubble test will be performed by operating personnel and recorded in the container's QA file in Building 3029 before the container can be used for loading encapsulated radioactive material.

b. An Inspection Engineering report on the internal weld dye penetrant inspection is valid for 6 months prior to shipment. If inspection is over 6 months old, a new dye penetrant inspection of the internal welds must be made and the results recorded in the QA file. All repairs will be inspected and approved by Inspection Engineering and recorded in the QA file.

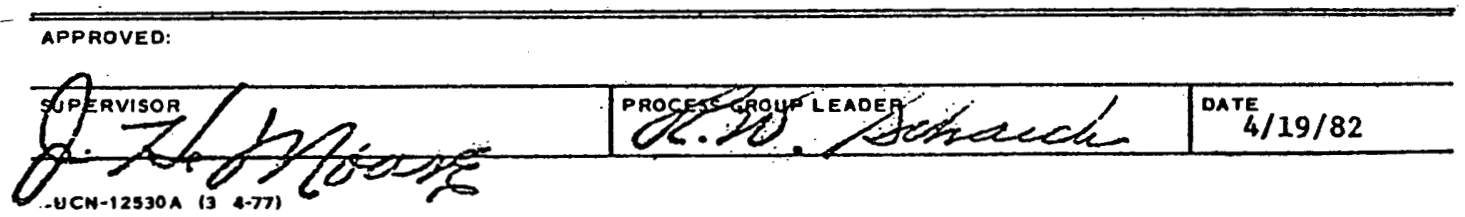




\title{
OPERATIONS DIVISION RADIOISOTOPE DEPARTMENT BUILDING 3029 \\ SOURCE DEVELOPMENT LABORATORY

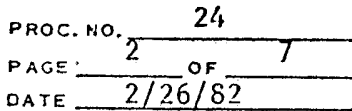 \\ PATE $2 / 26 / 82$
} QUALITY ASSURANCE PROCEDURE FOR TYPE B SHIPPING CONTAINERS

\begin{abstract}
c. Gaskets will be changed every 6 months and recorded in the container's QA file. Gasket material from stores stock must be verified by the store stock number.
\end{abstract}

2. Fire Shields

Fire shield lids and bolting devices will be inspected before shipment by the Packing Foreman to insure proper fit of the locking mechanism to hold the lid securely in place during transit. A record of this inspection is to be placed in the container's QA file. All repairs are to be made before shipment and the blanket work order with its completed form is to be filed in the container"s QA file.

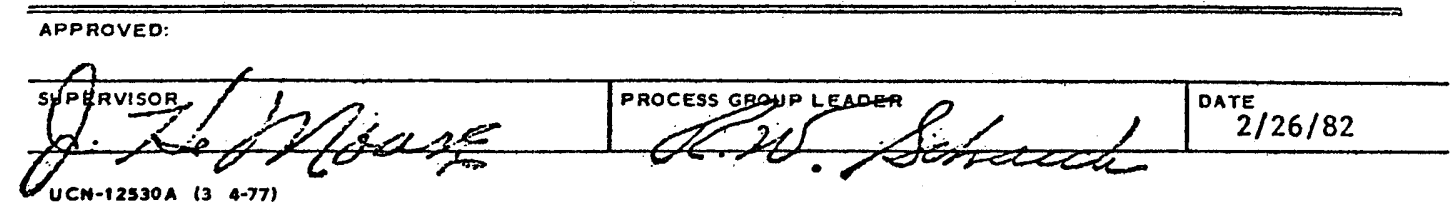




\section{OPERATIONS DIVISION RADIOISOTOPE DEPARTMENT BUILDING 3029 \\ SOURCE DEVELOPMENT LABORATORY} QUALITY ASSURANCE PROCEDURE FOR TYPE B SHIPPTNG CONTAINERS

\section{CONTAINER INSPECTION SHEET}

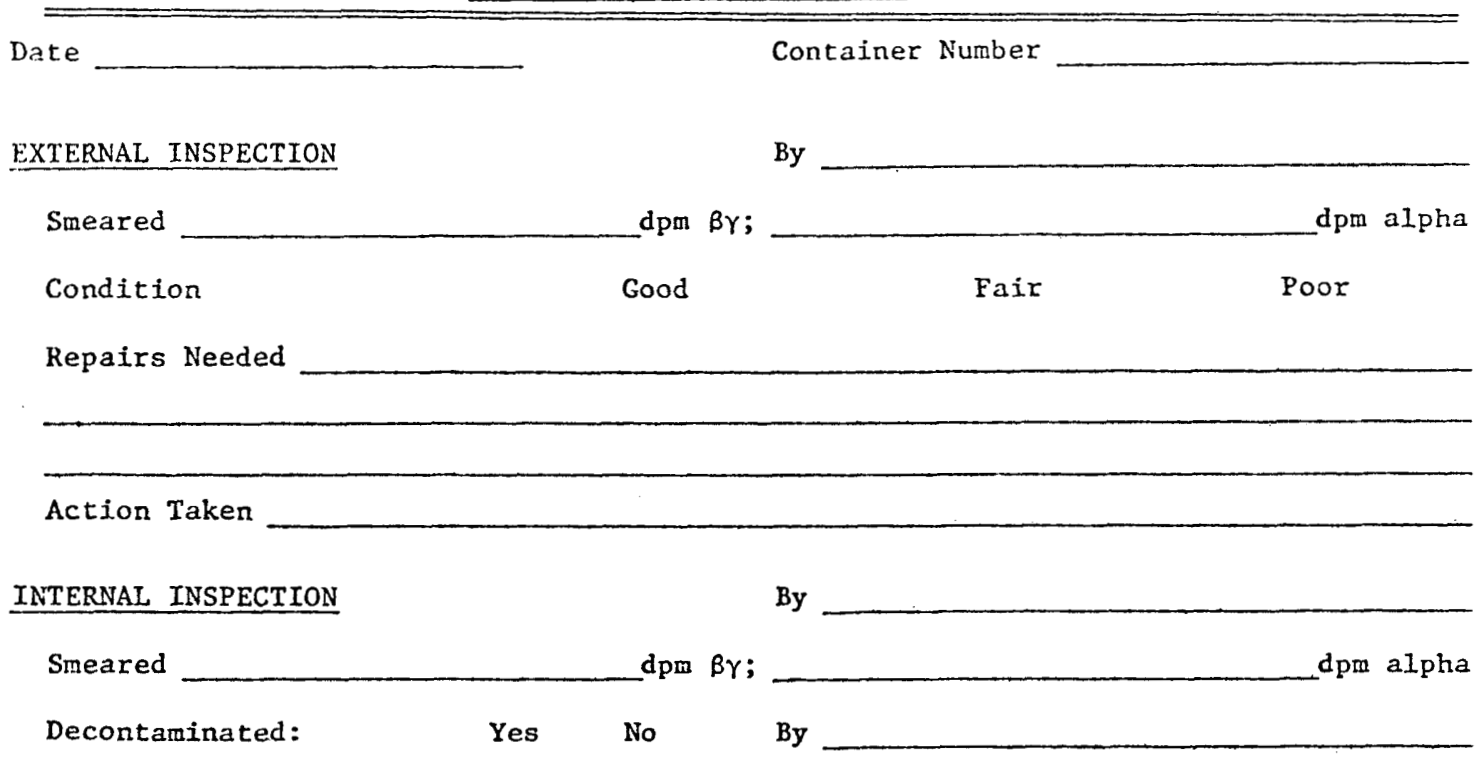

\section{CONTAINER TESTING}

Soap Bubble Test

Gaskets

Weld Dye Check Bolts \& Lock Washers

Repairs. Made

\section{RE-TESTING}

Soap Bubble Test

Weld Dye Check

CONTAINER CERTIFIED FOR SHIPMENT - Date

$$
\text { By }
$$

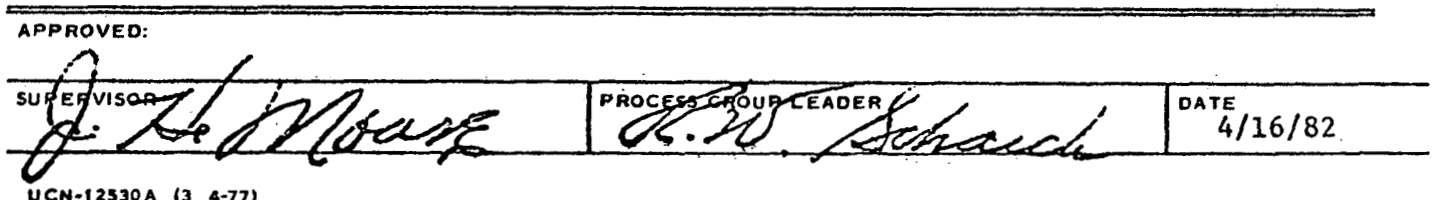




\section{OPERATIONS DIVISION RADIOISOTOPE DEPARTMENT BUILDING 3029 \\ SOURCE DEVELOPMENT LABORATORY} QUALITY ASSURANCE PROCEDURE FOR TYPE B SHIPPING CONTAINERS

\section{SUGARMAN CASK PACKING PROCEDURE}

Pre-Loading Check

1. Chokers for cask handling and lid removal checked for proper loading value and certification by Inspection Engineering

2. Soap bubble test (Leak rate $<1.0 \times 10^{-3} \mathrm{~atm} \cdot \mathrm{cm}^{3} / \mathrm{s}$ )

3. Inspection Engineering report date (If over 6 months

since last report, re-inspect)

PROC. NO. 24

PAGE 5 OF 7

DATE $4 / 16 / 82$

5. Cavity and lid smear level

By

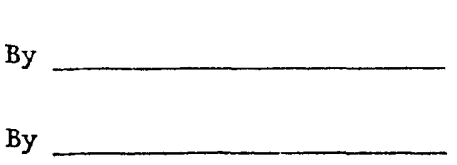

.

6. Outside cask surface smear level

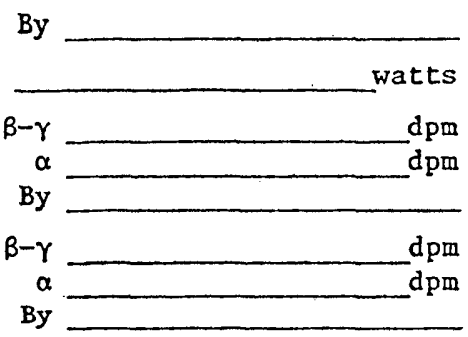

7. Lid closure cap screws, lockwashers, and nuts checked for burrs and proper operation

By

\section{Post Loading Check}

1. Outside cask surface smear level (clean to ORNL smear tolerance for shipping

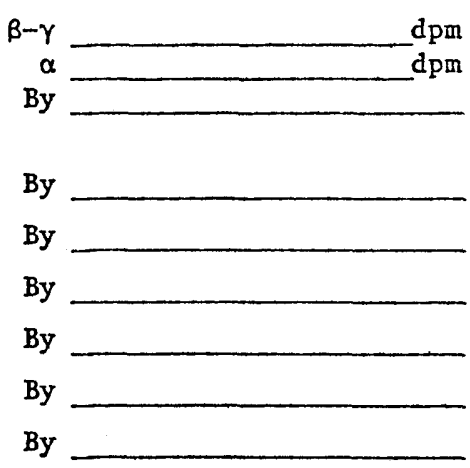

2. Lid closure cap screws free of burrs or damage from in-cell loading

3. Lid cap screws torqued to $150 \mathrm{ft} .-1 \mathrm{~b}$

4. Tamper seal installed

5. Loaded into Fire \& Impact Shield

6. Packaging Information Form (UCN-12301) completed

7. Notification to Packing and Shipping Foreman

Supervisor Approval by

Date

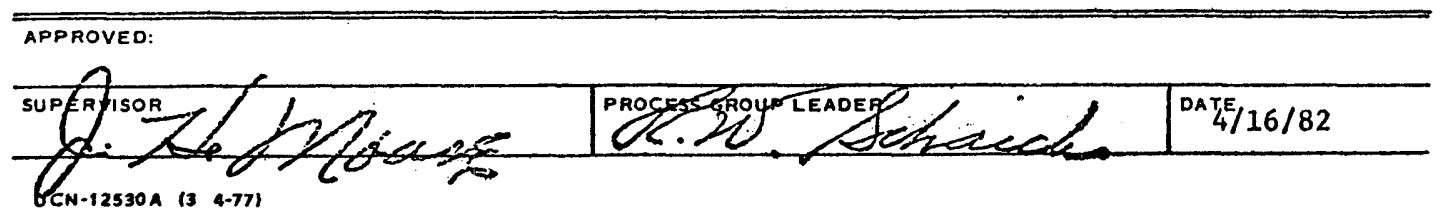




\section{OPERATIONS DIVISION RADIOISOTOPE DEPARTMENT BUILDINC; 3029 \\ SOURCE DEVELOPNENT LABORATORY \\ LEAK TESTING PROCEDURE FOR RADIOACTIVE MATERIALS \\ CONTAINED IN SPECIAL FORY CAPSULES}

I. Leak Testing

A. General

All radioactive mateials contained in Special Form or DOT $2 \mathrm{R}$ capsules are leak tested before shiprent. The method used is the air bubble, vacuium, and glycol as described in NNSI Standard

N14.C. A3. 6 .

B. Equiprent

1. The leak test equipment consists of a glass test chamber with a removable sealable top. A line penetrates the top and is connected to an in-cell vacuum pump. The size and shape of the test chamber may vary with the design of the piece being tested; and must be large enough that the piece can be zunpletely imrorsed in the test liquid, leaving at least oife inch of test liquid above the weld area.

2. Lacks, suspension assemblies, or similar positioning devices may be required for some radioactive sources. These will be designed so as not to interfere with observation of the weld area during testing.

3. Unless otherwise specified, the test liquid for liners is distilled water. The final test liquid for radioactive sources is ethylene glycol. The final leak test has a sensitivity greater than $1 \times 10^{-6}$ at. $\mathrm{cm}^{3} / \mathrm{sec}$.

c. Procedure

1. The test chamber is filled. with test liquid to a depth sufficient to cover the piece being tested and leave at least one inch, but not more than three inches, of test liquid above the weld area when the piece is in the test position.

2. The top is placed on the test chamber and a vacuum of at least 20 inches $\mathrm{Hg}$ is imposed.

3. The piece, and especially the weld area, is observed for 30 seconds while the vacuum is maintained. A leak is indicated by a steady stream of air bubbles coming from a fixed point on the source.

4. After the 30-second observation the vacuum 1s relieved; then the piece is removed from the test chamber.

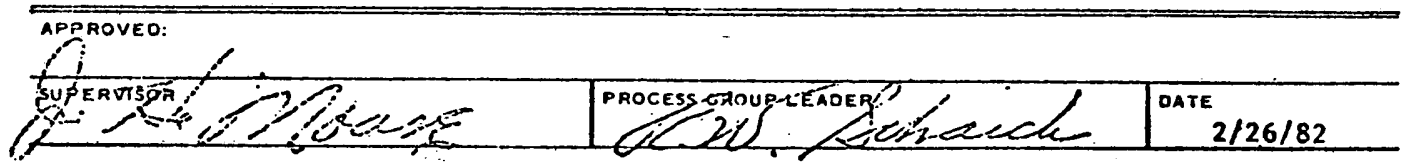

UCN-12530A (3 4-77) 


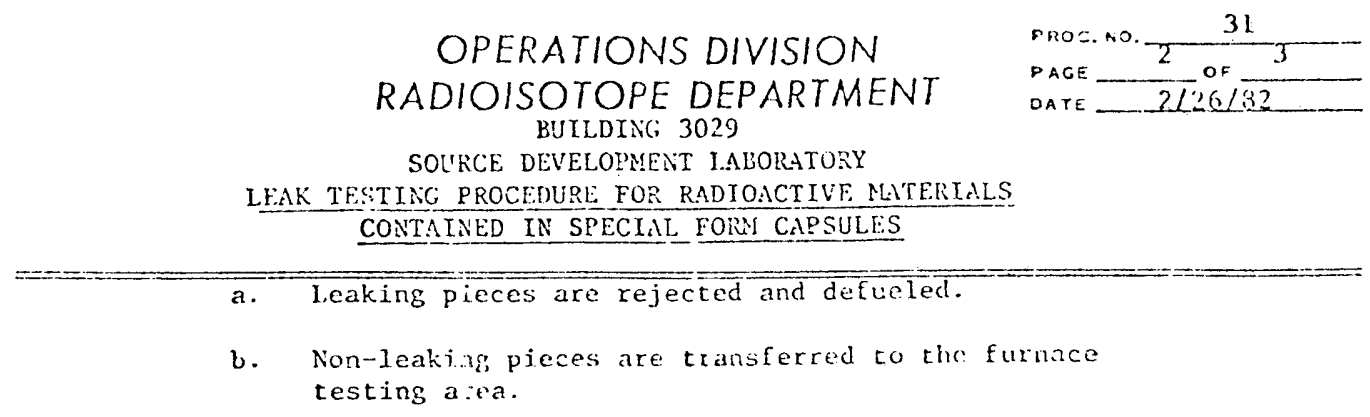

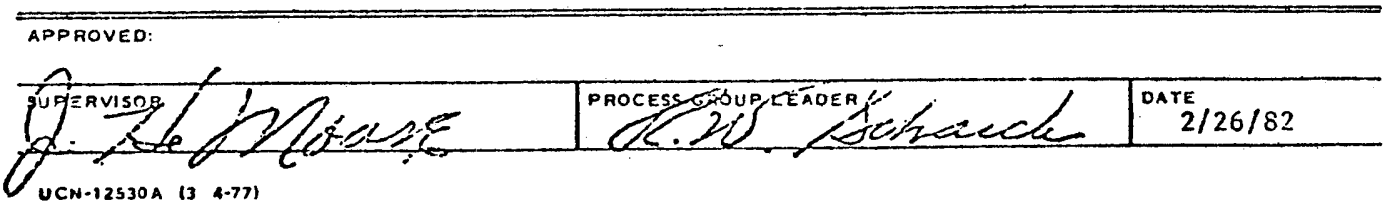




\section{OPERATIONS DIVISION RADIOISOTOPE DEPARTMENT BUILDING 3029 \\ mrocino. 31 \\ - ACE 3 - 2 DF 3 . DATE 2 L26/8?} SOURCF. DEVELOPNENIT LABORATOIY

LEAK TESTINC PROCEDURE FOR RADLOACTIVE MUELIANS CONIAT NED IN SPECIAL FORI CAPSULES

RADIOACIIVE SOURCE DATA SHEET

Cirstomer

S.N. No.

ivel Batch No.

init. Dim, $-0 . D$.

Capsule Comp.

Capsule \& Cap begreased

Iiner No.

iner Cleaned

Liner Dried (

Welding Procedire

iest Weld No.

Capsule Welded

Go-no-go Test

Jeak Test

oven fest (

Go-no-go Test

Leak Test

Decontaminated

Shelf Test Started

Shelf Test Completed

Re-smear

Go-no-go Test

Source Disposition
Capsule No.

ruel form

Curies

Assay

I.D.

Lengtlı

Cap. 'bl.

Spec. Sheet

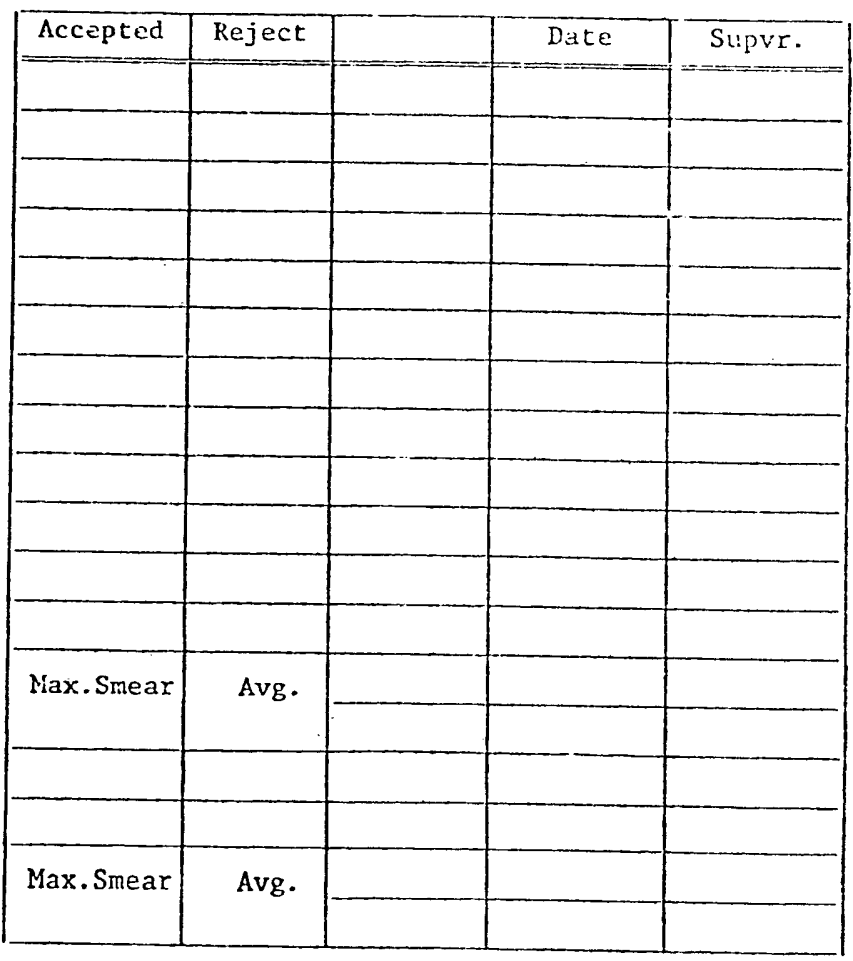

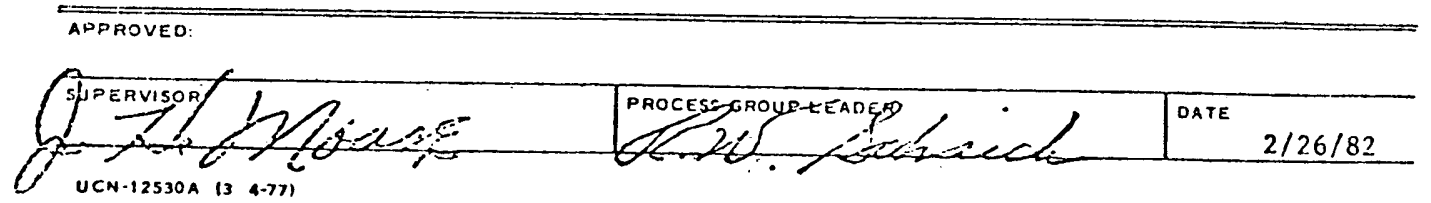


APPENDIX E

DRAWINGS AND SPECIFICATIONS 


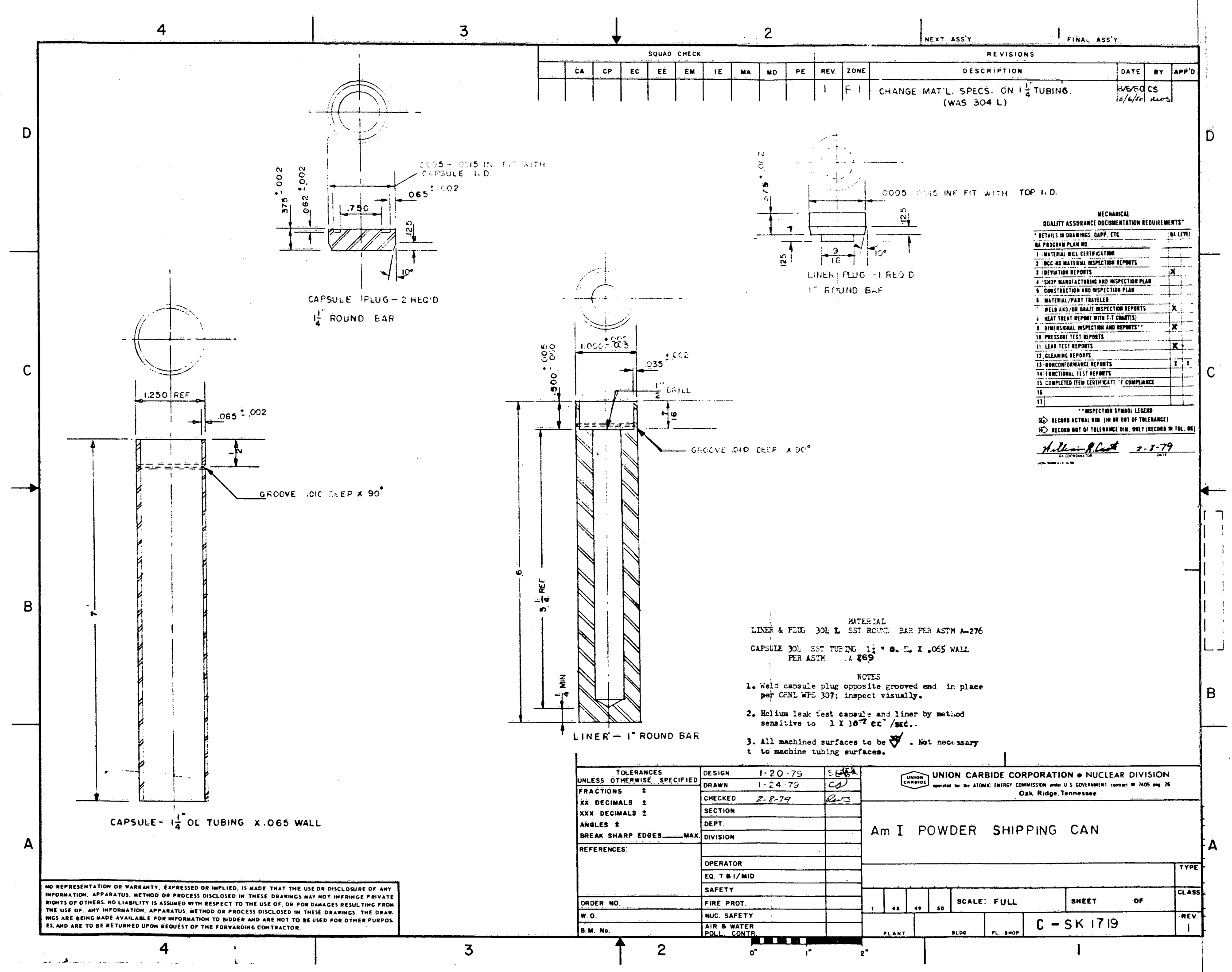




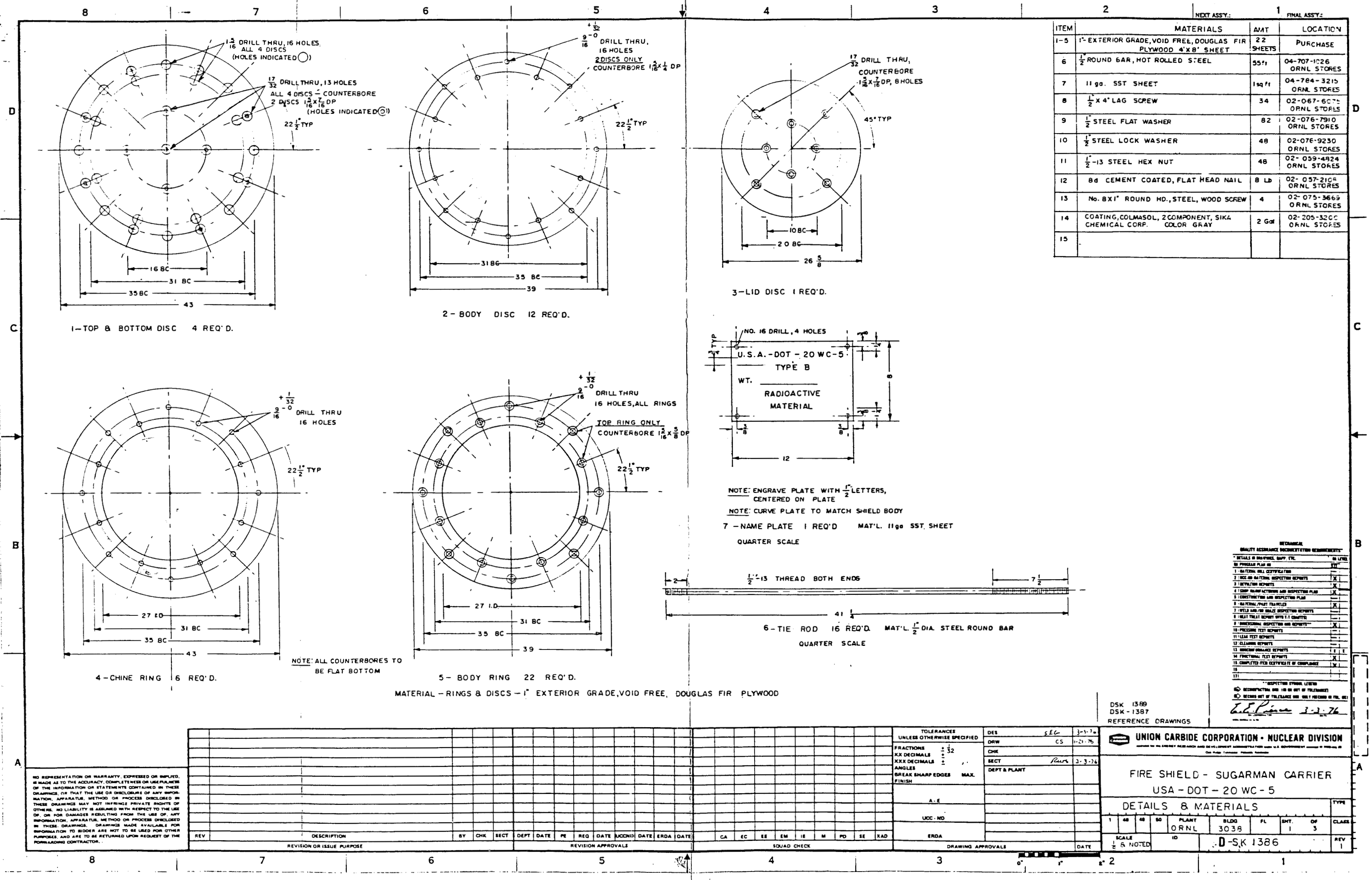




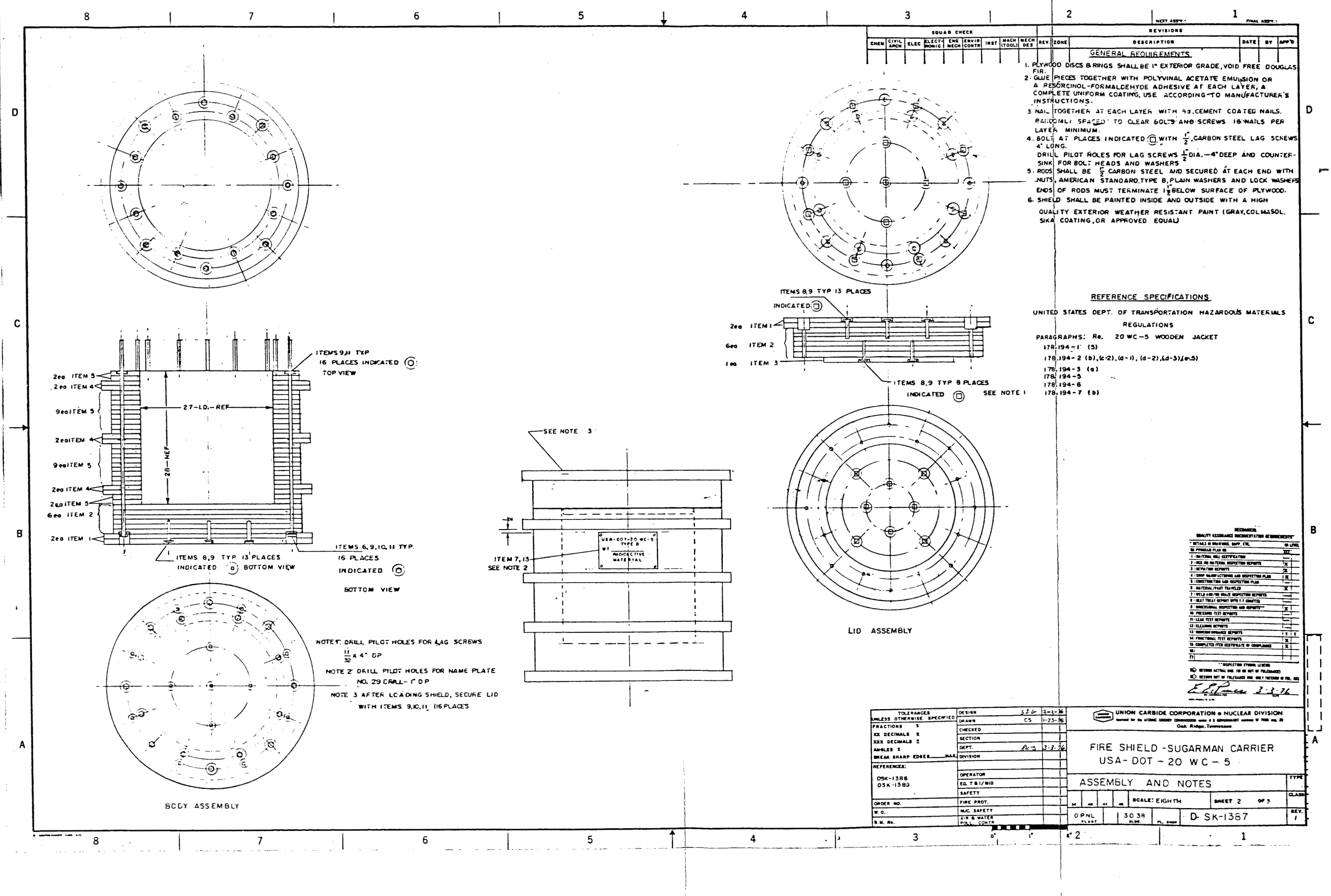




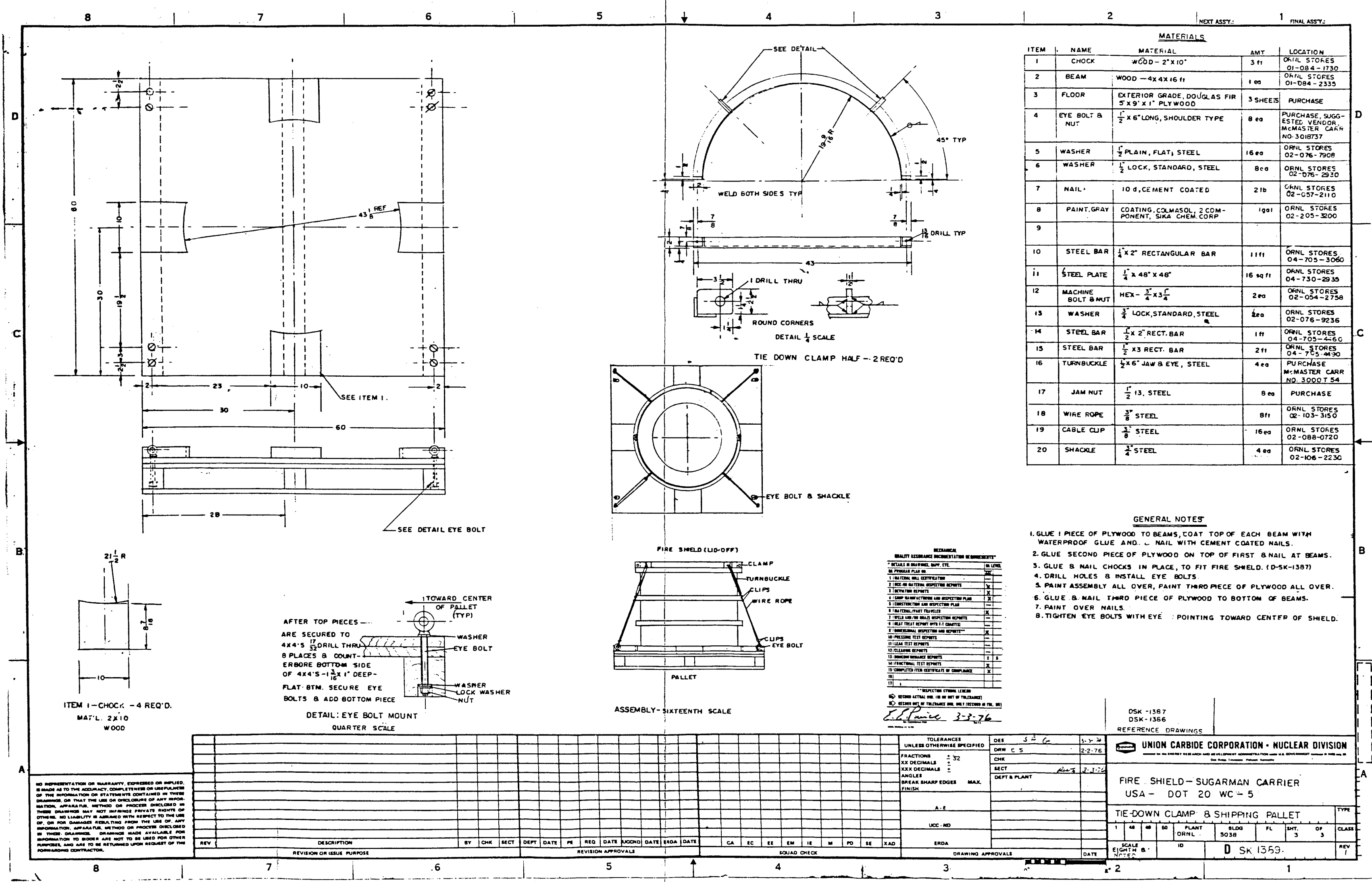




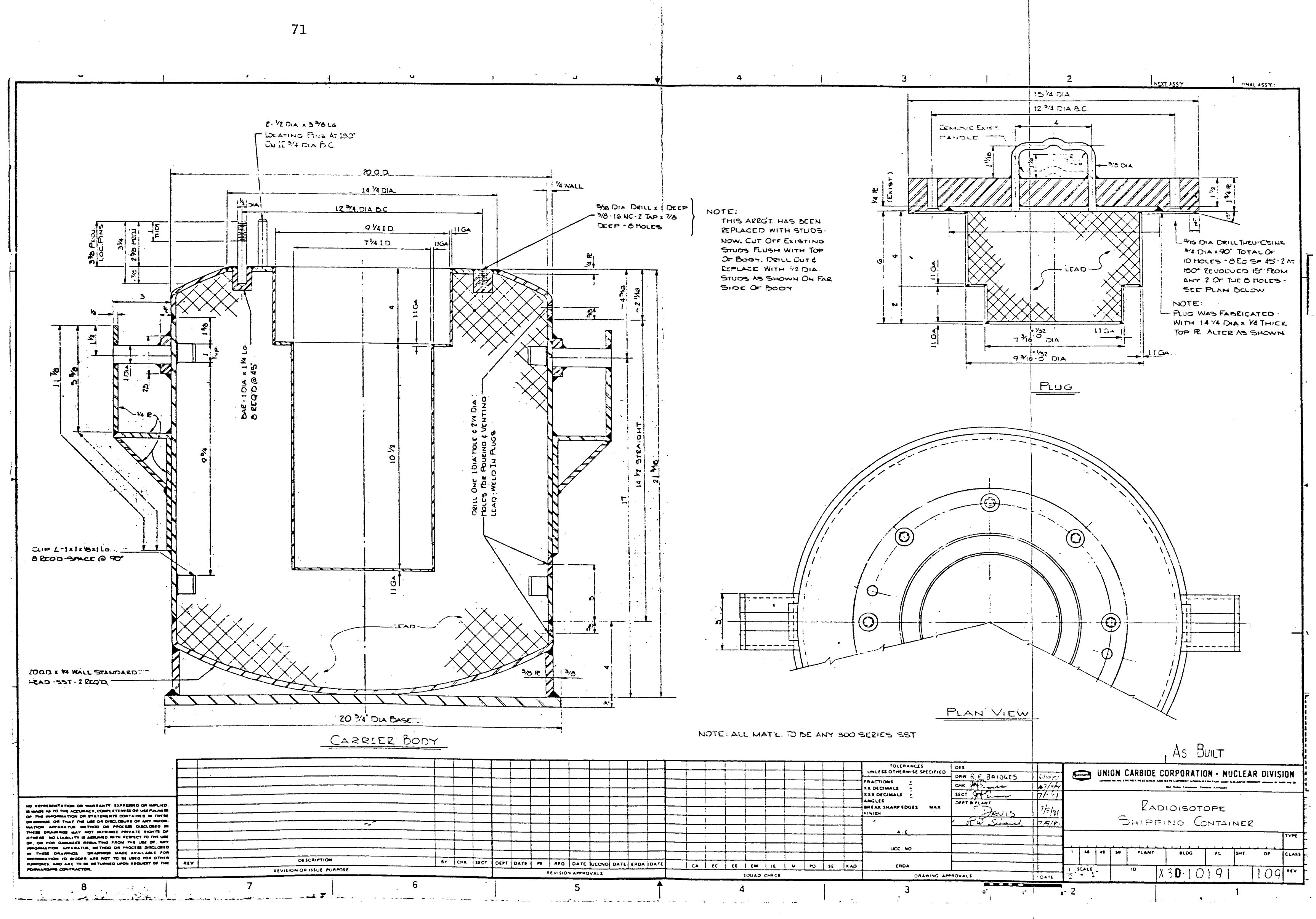



TITLE 49

CODE OF FEDERAL REGULATIONS

Part 178
"Yers (19.179,194-3 Cloqing surlace on each end. Ends of the rods must terminate 1.4 centimeters ( 0.75 inch) below the surface of the plywood for specifications 20WC-1 and 20wC-2. For specifications 20WC-3, 20WV-4, 20WC-5 and 20WC-6, the ends of the rods must terminate 3.7 centimeters ( 1.5 inches) below the surface of the plywood. and that portion of each end disc which extends beyond the rod ends must be further heid in place with lar screws at least 10 centimeters ( 4 inches) long.

(e) Thicinoss of wooden sholl:

(1) Specification 20WC-1: Al least 10 centimelers ( 1 inches) thick.

(2) Specilication 20wC-2: At lsast 7.5 centimeters ( 3 inches) thick.

(3) Specification 20:VC-3: At least 13 centimeters (5 inches) thick for the jacket wall. and at least 15 centimeters (6 inches) thick tor the end discs. In addition, at least 3 plywood chines, 5 centimeters (2 inches) wide and proirusing 5 centirneters ( 2 inches) beyond the ovier surlaces, must be located at each end and micivay along the lengih of the jacket.

(4) Specification 20WC-4: At least 15 centimeters (6 inches) thick for the jacket wall, and at least 15 centimelers ( 6 inches) thick for the end discs. In addition, at least 3 plywood chines, 5 centimeters (2 inches) wide and protruding 5 centimeters ( 2 inches) beyond the ouier surfaces, must be located at each end and midway along the length of the jacket.

(5) Specifications 20WC-5 and 20WC-6: At least 15 centimeters ( 6 inches) thick for the jacket wall, and at least 20 centimelers ( 8 inches) thick for the end discs. In addition, at least 5 piyrood chines. 5 centimeters ( 2 inches) wide and protruding 5 centimeters ( 2 inches) beyond the outer surfaces, must be located at each end and equally spaced along the length of the jacket.

$\$$ 178.194-3 Closure. (a) Closure for the wooder protective jacket is provided by the steet reinforcing rods. The end cap (lid) must fit tightly to the body of the jacket to prevent a heat path to the inside of the jacket. The lid joint for specifications $20 W C-3,20 W C-4,20 W C-5$, and 20WC-6, may not bə coplanar with the end of the inner containment vessel

(b) Specifications 20WC-2 and 20WC-6. Locking ring closure if used, must contorm to $\$ 178.104-4$. Flanged closure, if used, must have at least 3 steel bolts (at least 6 millimeters ( 0.25 inch) diameter for 20WC-2 or 1.2 centimeiers (0.50 inch) diameter for $20 \mathrm{WC}-6)$ and lock nuts (or equivalent device), spaced not mora than 13 centimeters ( 5 inches) between centers.

8 178.194-4 Tests. Prior to each use, each jacket must be visually inspected for defects such as improper bonding. cracking. corrosion of steel rods, and improperly filling closure lid, or other manufacturing defects. Particular attention must be given to any separation of the plywood discs and rings which would provide a heat path to the inside of the jacket.

\$ 178.194-5 Painling. Each jacket (other than 20WC-2 and 20WC-6) must be completely painted with a high quality exterior weather resistant paint.

6 178.194-6 Marking. (a) Each jacket must be marked on the external surace as follows: "USA-DOT-20WC-( ) TYPE 8 " The aopropriate numeral must be inserted in the marking to indicate the appropriate numeral must be inserted in the marking to ind

(b) Each jacket must also be marked with the name or symbol of person making the marks specified in paragraph (a) of this section. Symbol, if used, must be registered with the Associate Director for OE.

178.194-7 Typical assembly sketches. (a) Spec. 20WC-2.

(b) Specification 20WC-5

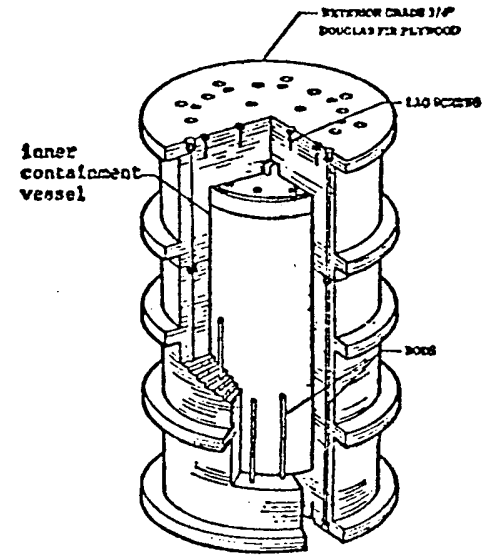


$\$ 173.394$ Aadioactive material In special form. (a) In addition to the applicable requirements of $\$ \$ 173.24$ and 173.393, a Type A quantity of special form radioactive material must be packaged as follows:

(1) Specification 7A (\$178.350 of this subchaoter) Type A general packaging. Each shipper of a Specification 7A packaging must maintain on file for at least one year after the latest shipment, and be prepared to provide the Department, a complete certification and supporting safety analysis demonstrating that the construction methods, packaging design, and materials of construction are in compliance with the specification. This requirement is effective December 31 , 1975.

(2) Specitication 55 ( $\$ 178.250$ of this subchapter) metal encased shielded container. Use of existing container authorized; construction not authorized after March 31, 1975.

(3) Any Type B packaging pursuant to paragraph (b) of this section

(4) Foreign-made packagings which bear the marking "TYPE A."

(b) Type B quantities of special form radioaclive materials must be packaged as follows:

(1) Specification 55 metal encased shielded container. Authorized only for domestic shipments of not more than 300 curies per package. Use of existing container authorized; construction not authorized after March 31, 1975

(2) Specification $6 \mathrm{M}$ ( $\$ 178.104$ of this subchapter) metal packaging.

(3) Any other Type 8 packaging approved by the U.S. Nuclear Regulatory Commission.

(4) Any other Type B packaging which meets the pertinent requirements in the 1967 regulations of the International Atomic Energy Agency, and for which the foreign competent authority certificate has been revalidated by the Department.

(5) Specification 20WC (\$178.194 of this subchapter) wooden outer protective jacket, with a single snug-fitting inner Type A packaging which has a metal outer wall and conforms to $\$ 178.350$ of this subchapter or Specification 55. Only use of existing specification 55 container authorized; construction not authorized after March 31 , 1975.

(6) Specification 21WC (\$178.195 of this subchapter) wooden-steel protective overpack, with a single inner specification $2 R(\$ 178.34$ of this subchapter) or specification 55, inner packaging. Only use of existing specification 55 container authorized construction not authorized after March 31, 1975. Contents must be loaded within the inner packaging to preclude loose movement during transportation. The inner packaging must be securely positioned and centered within th overpack by solid cushioning materials so that there would be no sig nificant displacement of the inner packaging if the packaging were subjected to the 9 meter $(30-f o o t)$ drop test described in $\$ 173.398(c)(1)$

(c) Large quantities of radioactive materials in special form must be packaged as follows:

(1) Spec. $6 \mathrm{M}$ ( $\$ 178.104$ of this subchapter) metal packaging. Radioactive thermal decay energy must not exceed 10 watts.

(2) Any other Type B packaging which meets the pertinent requirements for large quantities of radioactive materials in the regulations of the U.S. Nuclear Regulatory Commission (10 CFR Part 71) and is approved by the U.S. Nuclear Regulatory Commission.

(3) Any other Type B packaging which meets the pertinent requirements for large quantities of radioactive materials in the 1967 regulations of the Iniernational Atomic Energy Agency, and for which the foreign competent authority certificate has been revalidated by the Depariment.

(4) Specifications 20WC ( $\$ 178.194$ of this subchapter) wooden outer protective jacket, with a single, snug-fitting specification 55 inner packaging. Only use of existing specification 55 container authorized; construction not authorized after March 31, 1975. Radioactive thermal decay energy must not exceed 100 watts.

Title 49: Code of Federal Regulations 
ORNL/TM-8347/R1

Dist. Category UC-71

\section{DISTRIBUTION}

1. H. L. Adair

2. H. C. Austin

3. G. H. Burger

4. H. M. Butler

5. F. N. Case

6. H. C. Claiborne

7. J. R. DeVore

8. G. J. Dixon

9. J. H. Evans

10. K. W. Haff

11. E. M. King

12. E. Lamb

13. L. L. Leave11

14. R. V. McCord
15. J. M. Miller

16. F. H. Neill

17. E. Newman

18. J. E. Ratledge

19-23. R. W. Schaich

24. J. A. Setaro

25. L. B. Shappert

26. K. W. Sommerfeld

27. J. H. Swanks

28. W. E. Terry

29. Central Research Library

30. Document Reference Section

31-32. Laboratory Records Department

33. Laboratory Records, ORNL R.C.

34. ORNL Patent Office

\section{EXTERNAL DISTRIBUTION}

35. E. L. Baraclough, DOE, Albuquerque Operations Office, P.0. Box 5400, Albuquerque, New Mexico 87115.

36. R. I. Elder, DOE, Chicago Operations Office, 9800 South Cass Avenue, Argonne, Illinois 60439.

37. J. M. Freedman, Sandia National Laboratories, P.0. Box 5800, Albuquerque, New Mexico 87115.

38. Assistant Manager for Energy Research and Development, DOE, ORO.

39. W. G. O'Quinn, DOE, Savannah River Operations Office, P.O. Box A, Aiken, South Carolina 29801.

40. R. H. Odegaarden, NRC, Office of Regulation, Washington, D.C. 20545.

41. R. W. Peterson, Allied General Nuclear Services, P.0. Box 847 , Barnwe11, South Carolina 29812.

42-66. W. A. Pryor, DOE, ORO.

67. R. R. Raw1, U.S. Department of Transportation, 6th and D Street SW, Washington, D.C. 20590.

68-301. Given distribution as shown in TID-4500 under Category UC-71 Transportation of Property and Nuclear Materials (25 copies - NTIS). 